Estimated Effects of Projected

Ground-Water Withdrawals on

Movement of the Saltwater Front in the Floridan Aquifer, 1976-2000, West-Central Florida

United States

Geological

Survey

Water-Supply

Paper 2189
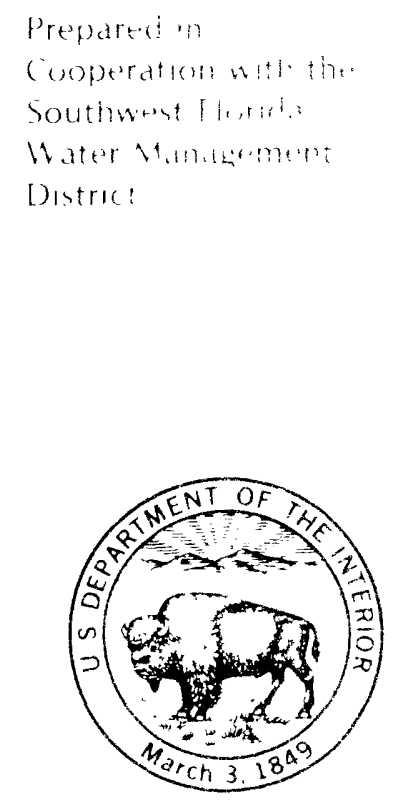


\title{
Estimated Effects of Projected Ground-Water Withdrawals on Movement of the Saltwater Front in the Floridan Aquifer, 1976-2000, West-Central Florida
}

\author{
By WILLIAM E. WILSON
}




\section{UNITED STATES DEPARTMENT OF THE INTERIOR}

James G. Watt, Secretary

GEOLOGICAL SURVEY

Dallas L. Peck, Director

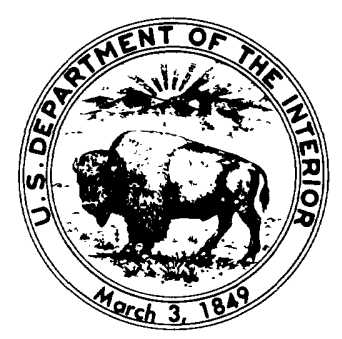

UNITED STATES GOVERNMENT PRINTING OFFICE:1982

For sale by the Superintendent of Documents

U.S. Government Printing Office

Washington, DC 20402

Library of Congress Cataloging in Publication Data

Wilson, William Edward, 1934-

Estimated effects of projected ground-water withdrawals on movement of the saltwater front in the Floridan aquifer,

1976-2000, west-central Florida.

(U.S. Ceological Survey water-supply paper; 2189)

Bibliography: $p$.

Supt. of Docs. no.: I 19.13:2189

1. Saltwater encroachment-Florida

2. Aquifers-Florida. I. Southwest Florida Water Manage-

ment District. II. Title. III. Series: Geological Survey water-

supply paper; 2189

GB1197.83 F6W54

$628.1^{\prime} 1$

81-607085

AACR2 


\section{CONTENTS}

\author{
Conversion factors IV \\ Abstract 1 \\ Introduction 1 \\ Hydrogeologic framework 2 \\ Chloride distribution 4 \\ Zone of transition 4 \\ Data 6 \\ Complexity 8
}

Saltwater-freshwater interface $\mathbf{1 0}$

Ground-water withdrawals $\mathbf{1 1}$

Simulated potentiometric surface

Ground-water flow model 12

Results 14

Estimated movement of saltwater front

Spring conditions 15

Fall conditions 18

Discussion 20

Regional observation wells $\mathbf{2 1}$

Summary and conclusions $\mathbf{2 2}$

References $\mathbf{2 3}$

FIGURE

1-8. Maps showing:

1. Location of study and modeled areas 3

2. Altitude of base of the Floridan aquifer $\mathbf{5}$

3. Altitude of top of major water-bearing zone of the Floridan aquifer 6

4. Potentiometric surface of the Floridan aquifer under predevelopment conditions 7

5. Potentiometric surface of the Floridan aquifer, September $1976 \quad 8$

6. Potentiometric surface of the Floridan aquifer, May 19769

7. Chloride concentration in the lower part of the Floridan aquifer $\mathbf{1 0}$

8. Theoretical equilibrium position of saltwater-freshwater interface under predevelopment conditions $\mathbf{1 2}$

9. Section showing conceptual view of relationships between theoretical predevelopment equilibrium interface and observed chloride distribution in lower part of the Floridan aquifer 13

10. Graph of ground-water withdrawal rates for 1975 and projections for 1985 and $2000 \quad 14$ 
11. Diagram of generalized conceptual model of steady-state flow $\mathbf{1 5}$

12-15. Maps showing:

12. Simulated changes in potentiometric surface due to projected ground-water withdrawals, May 1976-May $2000 \quad 16$

13. Simulated potentiometric surface, May $2000 \quad 17$

14. Simulated changes in potentiometric surface due to projected ground-water withdrawals, November 1976October 200018

15. Simulated potentiometric surface, October 200019

16. Sections used to calculate ground-water flow velocity $\mathbf{2 0}$

17. Graph showing rate of ground-water flow at saltwater front $\mathbf{2 1}$

TABLE

1. Hydrogeologic framework 4

2. Velocity of ground-water flow near the saltwater front, spring conditions $\mathbf{2 1}$

\section{Conversion Factors}

For readers who prefer to use metric (SI) units rather than inch-pound units, conversion factors for terms used in this report are listed below:

\begin{tabular}{|c|c|c|}
\hline Multiply inch-pound unit & By & To obtain metric (SI) unit \\
\hline \multicolumn{3}{|c|}{ Length } \\
\hline foot $(\mathrm{ft})$ & 0.3048 & meter $(\mathrm{m})$ \\
\hline mile (mi) & 1.609 & kilometer $(\mathrm{km})$ \\
\hline \multicolumn{2}{|r|}{ Area } & square kilometer $\left(\mathrm{km}^{2}\right)$ \\
\hline \multicolumn{3}{|c|}{ Flow } \\
\hline $\begin{array}{l}\text { million gallons per day } \\
\qquad(\mathrm{Mgal} / \mathrm{d})\end{array}$ & 0.04381 & $\begin{array}{l}\text { cubic meter per second } \\
\qquad\left(\mathrm{m}^{3} / \mathrm{s}\right)\end{array}$ \\
\hline \multicolumn{3}{|c|}{ Transmissivity } \\
\hline $\begin{array}{l}\text { foot squared per day } \\
\qquad\left(\mathrm{ft}^{2} / \mathrm{d}\right)\end{array}$ & 0.09290 & $\begin{array}{l}\text { meter squared per day } \\
\qquad\left(\mathrm{m}^{2} / \mathrm{d}\right)\end{array}$ \\
\hline \multicolumn{3}{|c|}{ Leakance } \\
\hline $\begin{array}{l}\text { gallon per day per cubic } \\
\text { foot }\left[(\mathrm{gal} / \mathrm{d}) / \mathrm{ft}^{3}\right]\end{array}$ & 0.1337 & $\begin{array}{l}\text { meter per day per meter } \\
\qquad[(\mathrm{m} / \mathrm{d}) / \mathrm{m}]\end{array}$ \\
\hline
\end{tabular}

National Geodetic Vertical Datum of 1929 (NGVD of 1929). - A geodetic datum derived from a general adjustment of the first-order level nets of both the United States and Canada, formerly called "mean sea level." The datum was derived from the average sea level during many years at 26 tide stations along the Atlantic, Pacific, and Gulf of Mexico coasts. "NGVD of 1929" is referred to as "sea level" in this report. 


\title{
Estimated Effects of Projected Ground-Water Withdrawals on Movement of the Saltwater Front in the Floridan Aquifer, 1976-2000, West-Central Florida
}

\author{
By William E. Wilson
}

\section{Abstract}

Maps of observed 1976 and simulated 2000 potentiometric surfaces were used to estimate rates of saltwater encroachment and theoretical predevelopment equilibrium positions of the saltwater-freshwater interface in west-central Florida. The observed saltwater front, defined by the 19,000 milligrams-per-liter line of equal chloride concentration in the lower part of the Floridan aquifer, corresponds closely to a theoretical predevelopment equilibrium position of a saltwater-freshwater interface. The interface position was computed by the Chyben-Herzberg method, using heads from a map of the predevelopment potentiometric surface.

In maps of both the observed May 1976 and simulated May 2000 potentiometric surface, the saltwater front was within a large seasonal cone of depression in parts of Hillsborough, Manatee, and Sarasota Counties. Average landward flow rate of the front was computed to be 0.30 foot per day in May 1976 and 0.36 foot per day in May 2000. Seaward potentiometric-surface gradient under simulated October 2000 conditions averaged $8.8 \times 10^{-5}$ foot per foot less than under observed September 1976 conditions.

Regional observation wells are desirable for monitoring potentiometric-level changes in western Hardee County and eastern Manatee County and for monitoring waterquality changes along the saltwater front, on its landward side, from mid-Sarasota County northward to Hillsborough County.

Net landward movement of the saltwater front in the lower part of the Floridan aquifer is probably occurring under existing conditions. Pumping during 1976-2000 would probably increase slightly the rate of movement. However, rates are so slow that on a regional basis saltwater encroachment under existing and projected conditions is not presently a threat to the existing freshwater resources. The maximum projected regional landward movement, under "worst case" conditions, of the saltwater front between 1976 and 2000 is estimated to be about one-half mile. Significant local encroachment could result from (1) ground-water development in the zone of transition and (2) deviations of local hydrogeologic conditions from average regional conditions.

\section{INTRODUCTION}

Projections of water use in west-central Florida suggest that, during 1976-2000, ground-water withdrawals from the Floridan aquifer will increase by about 30 percent, and that significant shifts in the geographic distribution of withdrawals will occur (U.S. Environmental Protection Agency, 1979). The increased withdrawals will be principally for municipal and irrigation usage. The geographic shifts will be in withdrawal usage for phosphate mining, the center of which is expected to move from Polk County southward and westward to Hillsborough, Manatee, Hardee, and DeSoto Counties, as the Polk County ore becomes depleted. Usage for phosphate industry chemical plants is expected to remain relatively constant both in quantity and location.

These anticipated changes would affect both the local and regional ground-water flow system of the area. In 1975, the U.S. Geological Survey, in cooperation with the Southwest Florida Water Management District, began an investigation to assess changes in the potentiometric surface of the Floridan aquifer and the possible movement of saltwater in the Floridan aquifer as a result of these projected ground-water withdrawals.

The investigation was conducted in two phases. The objective of phase I was to determine the amount of expected change in the potentiometric surface as a result of proposed or anticipated ground-water development. The objective of phase I was accomplished principally through the calibration and application of a regional two-dimensional digital model of ground-water flow. The results were presented in several reports (Wilson, 1977a; Wilson and Gerhart, 1979a,b). The final report of phase I (Wilson and Gerhart, 1979a) included detailed descriptions of the hydrogeology of the modeled area, ground-water withdrawals, model input parameters, calibration procedures, and procedures for simulating changes in the potentiometric surface of the Floridan aquifer.

The objective of phase II was to evaluate the effects of simulated changes of the Floridan aquifer potentiometric surface on movement of the saltwater front. This report presents the results of phase 11 . Simulated potentiometric levels from phase 1 were used to estimate the rate of inland movement of the saltwater front in the lower part of the Floridan aquifer in coastal areas. The estimates were based on model results of the first phase of the investigation and on available information on the distribution of chloride concentrations in water in the Floridan aquifer. The estimates were made primarily to provide a sense of the magnitude and the general location of potential changes. The results of the 
investigation can je used as a guide for establishing or modifying monitoring-well networks until better techniques for modeling saltwater movement become operational.

This report is concerned primarily with the effects of major inland ground-water development on the occurrence and movement of saltwater in the lower part of the Floridan aquifer. The results do not show, for example, the effects of coastal ground-water development, nor the effects of any ground-water development on the occurrence and movement of saltwater in aquifers underlying or overlying the lower part of the Floridan aquifer.

The study area covers $3,533 \mathrm{mi}^{2}$ in west-central Florida, southeast of Tampa (fig. 1). 1n order to determine the effects of ground-water development, hydrogeologic data were evaluated and a ground-water flow model was calibrated for a larger region. The modeled area covers $5,938 \mathrm{mi}^{2}$ (fig. 1).

\section{HYDROGEOLOGIC FRAMEWORK}

Principal aquifers in the study area are the surficial aquifer and the Floridan aquifer. The aquifers are separated by a confining bed, and the Floridan aquifer is underlain by a lower confining bed. The following summary of the hydrogeologic framework is principally from Wilson and Gerhart (1979a); a more detailed discussion of the hydrogeology is contained in that report. Stratigraphic and lithologic descriptions of the hydrogeologic units are summarized in table 1.

The surficial aquifer is predominantly fine to very fine sand and clayey sand and is generally a few tens of feet thick. Ground water in the surficial aquifer is unconfined. The water table fluctuates seasonally about $2-5$ feet.

The Floridan aquifer is predominantly limestone and dolomite and includes all or parts of the Avon Park Limestone, Ocala Limestone, Suwannee Limestone, and Tampa Limestone (table 1). The top of the Floridan aquifer is the horizon below which carbonate rocks persistently occur. 1n the modeled area, this surface generally coincides with the top of either the Tampa Limestone or Suwannee Limestone. The base of the aquifer is at the top of the first persistently occurring intergranular evaporites in the carbonate rocks, usually coincident with the top of the Lake City Limestone. The altitude of the base of the aquifer ranges from about 900 feet to about 2,600 feet below sea level, as shown in figure 2 . This map is a revision of a preliminary map of the aquifer base in Wilson and Gerhart (1979a, fig. 6, p. 16).

Thickness of the Floridan aquifer in the modeled area ranges from about 900 to about 1,900 feet; trans- missivity ranges from 80,000 to $500,000 \mathrm{ft} 2 / \mathrm{d}$; and storage coefficient ranges from about $8.8 \times 10^{-4}$ to $1.9 \times 10^{-3}$.

The most transmissive part of the aquifer, or its major water-bearing zone, generally occurs within the upper few hundred feet of the dolomitic section of the Avon Park Limestone. The altitude of the top of this major water-bearing zone ranges from about 400 feet to about 1,600 feet below sea level (fig. 3). $1 \mathrm{n}$ this report, the section between the top of the major water-bearing zone and the base of the Floridan aquifer is referred to as the lower part of the Floridan aquifer. The thickness of the lower part of the Floridan aquifer is $600-800$ feet in most of the modeled area.

The upper confining bed of the Floridan aquifer may include all or part of the Caloosahatchee marl, Bone Valley Formation, Tamiami Formation, Hawthorn Formation, Tampa Limestone, and other undifferentiated predominantly clastic deposits of late Miocene to Pleistocene age (table 1). The rocks consist of phosphatic clay, sand, marl, limestone, and dolomite. These rocks may contain minor artesian aquifers, particularly in the southern part of the area. Thickness of the upper confining bed ranges from about 20 to 780 feet; vertical hydraulic conductivity ranges from about $8.6 \times 10^{-4}$ to $2.6 \times 10^{-2} \mathrm{ft} / \mathrm{d}$, as determined principally by model calibration; leakance coefficient ranges from about $1 \times 10^{-5}$ to $1 \times 10^{-3}\left[(\mathrm{gal} / \mathrm{d}) / \mathrm{ft}^{2}\right] / \mathrm{ft}$; and storage coefficient ranges from about $2.0 \times 10^{-4}$ to $7.8 \times 10^{-3}$.

The lower confining bed of the Floridan aquifer includes the Lake City, Oldsmar, and Cedar Keys Limestones (table 1). For modeling purposes, the lower confining bed was considered to be impermeable.

Downward leakage occurs in most inland areas from the surficial aquifer to the Floridan aquifer through the upper confining bed; upward leakage occurs along coastal areas and along incised valleys of major streams. (See fig. 11.)

Figure 4 shows the generalized configuration of the potentiometric surface of the Floridan aquifer under predevelopment conditions. The map was modified from that of Stringfield (1936) and is based on additional data in areas where the potentiometric level is believed to have remained unchanged (P. D. Ryder, written commun., 1979). The map represents conditions prior to significant regional pumping stresses. At that time, the major feature of the potentiometric surface was a dome or ridge in the northeastern part of the modeled area. Ground-water flow was generally coastward from this dome.

Man's activities in the last few decades have altered details in the configuration of the potentiometric 

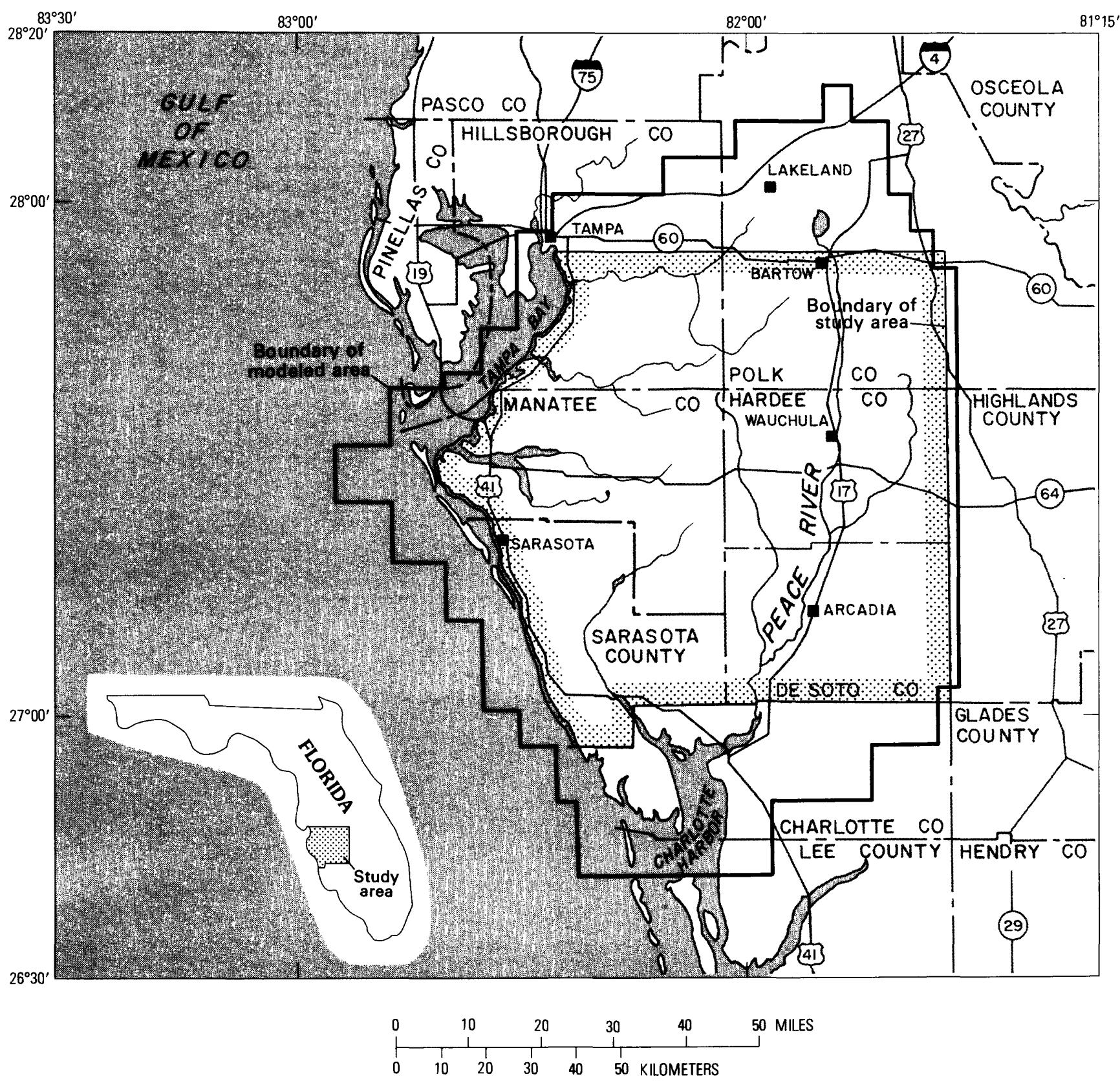

Figure 1. Location of study and modeled areas

surface, although the major dome and westward flow have remained intact, as shown by comparison of figure 4 with the potentiometric-surface map for September 1976 (fig. 5). This latter map represents conditions typical of the time of seasonally high water levels, following the summer rainy season, during which little or no pumping for irrigation occurred. The pattern of flow is substantially altered each spring, as shown by the poten- tiometric-surface map for May 1976 (fig. 6). This map represents conditions at the time of seasonally low water levels, at the end of a period when pumping for irrigation is commonly at a maximum; this period usually occurs from early November through early May. These stresses result in the seasonal occurrence of a large cone of depression centered in Manatee County (fig. 6). The cone of depression in May 1976 is similar to the cone mapped each May from 1975 through 1978. 
Table 1.-Hydrogeologic framework

\begin{tabular}{|c|c|c|c|c|c|}
\hline System & Series & $\begin{array}{l}\text { Stratigraphic } \\
\text { unit }\end{array}$ & General lithology & $\begin{array}{l}\text { Major } \\
\text { lithologic } \\
\text { unit }\end{array}$ & $\begin{array}{l}\text { Hydrogeologic } \\
\text { unit }\end{array}$ \\
\hline \multirow[t]{2}{*}{ Quaternary } & \multirow[t]{2}{*}{$\begin{array}{l}\text { Holocene, } \\
\text { Pleistocene, } \\
\text { Pliocene }\end{array}$} & Surficial sand & $\begin{array}{l}\text { Predominantly fine sand; inter- } \\
\text { bedded clay, marl, shell, lime- } \\
\text { stone, phosphorite. }\end{array}$ & Sand & Surficial aquifer \\
\hline & & $\begin{array}{l}\text { Undifferentiated } \\
\text { deposits }^{1}\end{array}$ & $\begin{array}{l}\text { Clayey and pebbly sand, clay, marl, } \\
\text { and shell; phosphatic. }\end{array}$ & \multirow[t]{2}{*}{$\begin{array}{l}\text { Carbonate and } \\
\text { clastic }\end{array}$} & \multirow{2}{*}{$\begin{array}{l}\text { Upper confining } \\
\text { bed of Flori- } \\
\text { dan aquifer }\end{array}$} \\
\hline \multirow[t]{6}{*}{ Tertiary } & Miocene & $\begin{array}{l}\text { Hawthorn } \\
\text { Formation }\end{array}$ & $\begin{array}{l}\text { Dolomite, sand, clay, and lime- } \\
\text { stone; silty, phosphatic. }\end{array}$ & & \\
\hline & & $\begin{array}{l}\text { Tampa } \\
\text { Limestone }\end{array}$ & $\begin{array}{l}\text { Limestone, sandy, phosphatic, fos- } \\
\text { siliferous; sand and clay in lower } \\
\text { part in some areas. }\end{array}$ & \multirow{4}{*}{ Carbonate } & \multirow{4}{*}{ Floridan aquifer } \\
\hline & Oligocene & $\begin{array}{l}\text { Suwannee } \\
\text { Limestone }\end{array}$ & $\begin{array}{l}\text { Limestone, sandy limestone, } \\
\text { fossiliferous. }\end{array}$ & & \\
\hline & \multirow[t]{3}{*}{$\begin{array}{l}\text { Eocene, } \\
\text { Paleocene }\end{array}$} & $\begin{array}{l}\text { Ocala } \\
\text { Limestone }\end{array}$ & $\begin{array}{l}\text { Limestone, chalky, foraminiferal, } \\
\text { dolomitic near bottom. }\end{array}$ & & \\
\hline & & $\begin{array}{l}\text { Avon Park } \\
\text { Limestone }\end{array}$ & $\begin{array}{l}\text { Limestone and hard brown dolo- } \\
\text { mite. }\end{array}$ & & \\
\hline & & $\begin{array}{l}\text { Lake City, } \\
\text { Oldsmar, and } \\
\text { Cedar Keys } \\
\text { Limestones }\end{array}$ & $\begin{array}{l}\text { Dolomite and chalky limestone, } \\
\text { with intergranular gypsum and } \\
\text { anhydrite. }\end{array}$ & $\begin{array}{l}\text { Carbonate } \\
\text { with inter- } \\
\text { granular } \\
\text { evaporites. }\end{array}$ & $\begin{array}{l}\text { Lower confining } \\
\text { bed of Flori- } \\
\text { dan aquifer. }\end{array}$ \\
\hline
\end{tabular}

${ }^{1}$ Includes all or parts of Caloosahatchee Marl, Bone Valley Formation, and Tamiami Formation.

Potentiometric-surface maps and hydrographs of ground-water levels indicate a general downward trend in annual peaks and an increase in range between seasonal lows and highs, especially since the 1960's. These changes reflect increased irrigation demand.

\section{CHLORIDE DISTRIBUTION}

Chloride concentrations in water in the Floridan aquifer range widely in the modeled area. In much of the inland area, chloride concentrations are 10-25 $\mathrm{mg} / \mathrm{L}$. Water having chloride concentrations in this range can be considered "background water," or fresh ground water unmixed with saltwater. Along the coast, at least part of the Floridan aquifer contains saltwater; chloride concentration is commonly about 19,000 $\mathrm{mg} / \mathrm{L}$, or approximately the same as Gulf of Mexico seawater. The surface expressed by the $19,000-\mathrm{mg} / \mathrm{L}$ line of equal chloride concentration is, therefore, de- fined as the saltwater front. A zone of transition exists between the saltwater front in coastal areas and "background water"' in inland areas.

\section{Zone of Transition}

In the zone of transition, the aquifer contains water that has chloride concentrations predominantly intermediate between those of "background water" and saltwater. The chloride concentrations are variable, both areally and with depth, and even within the zone some parts may contain water with chloride concentrations similar either to those of "background water" or to saltwater. According to Cooper $(1964, \mathrm{p}$. C8), the principal mechanism for developing a zone of transition is the reciprocative motion of the saltwater front, resulting from tidal action, and the rise and fall of the potentiometric surface due to variations in recharge and other forces, including pumping. 

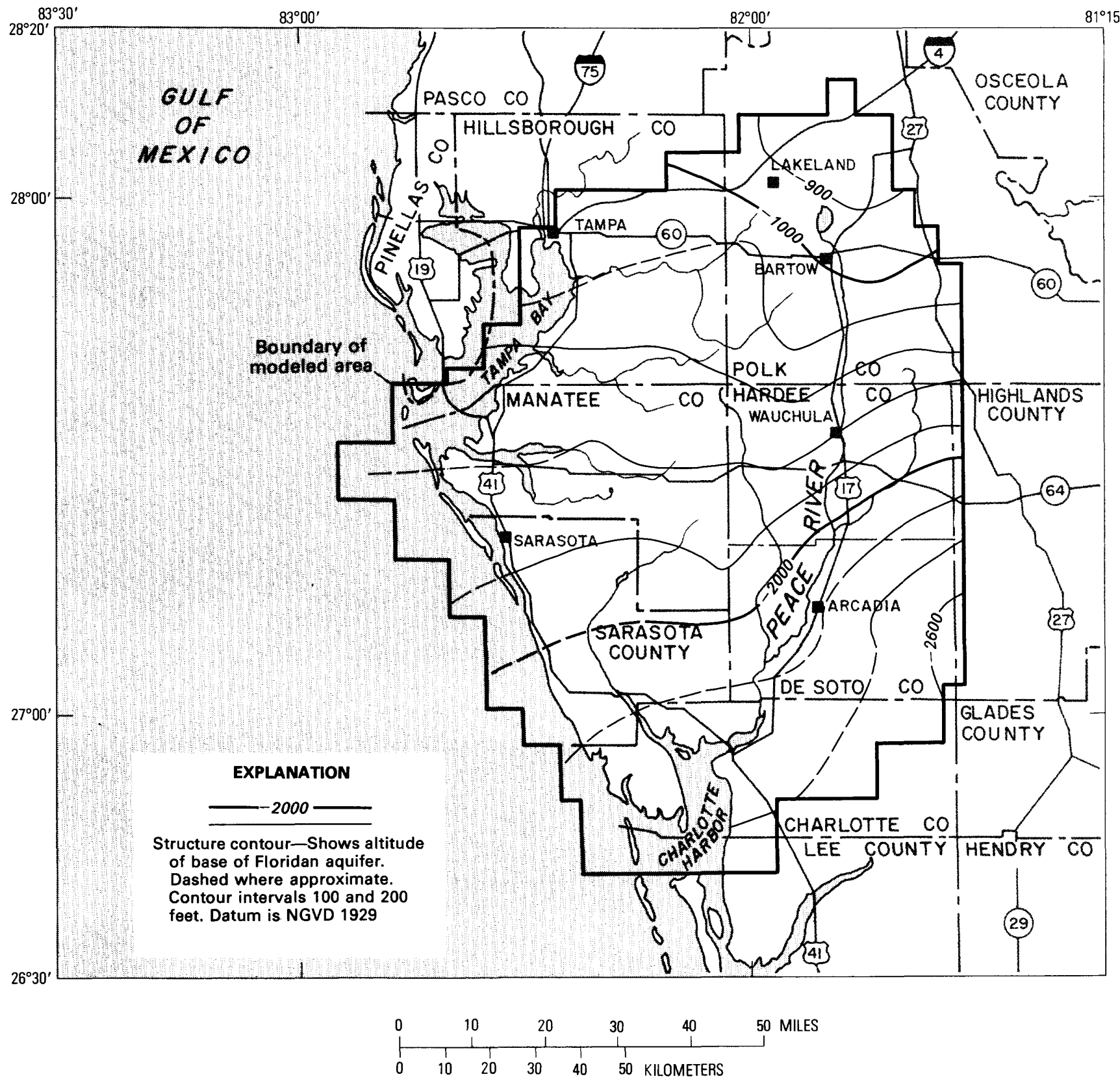

Figure 2. Altitude of base of the Floridan aquifer.

Figure 7 shows the approximate extent of the zone of transition in the lower part of the Floridan aquifer. Mapping was done for the lower part of the aquifer because this part is the most highly developed by wells, contains the most highly transmissive part of the aquifer, and has the most available data.

In figure 7, the line marking the coastal boundary of the zone of transition represents the approximate position of the saltwater front at the top of the lower part of the Floridan aquifer. Thus, coastward of this line, the entire lower part of the aquifer contains salt- water. Similarly, landward from the inland boundary of the zone, the entire lower part of the aquifer contains fresh water.

The zone of transition broadens from about 3 miles wide in part of Hillsborough County to several tens of miles wide in the southeastern part of the modeled area. Beneath most of Sarasota, DeSoto, and Charlotte Counties, the lower part of the Floridan aquifer contains either saltwater or water in the zone of transition. 

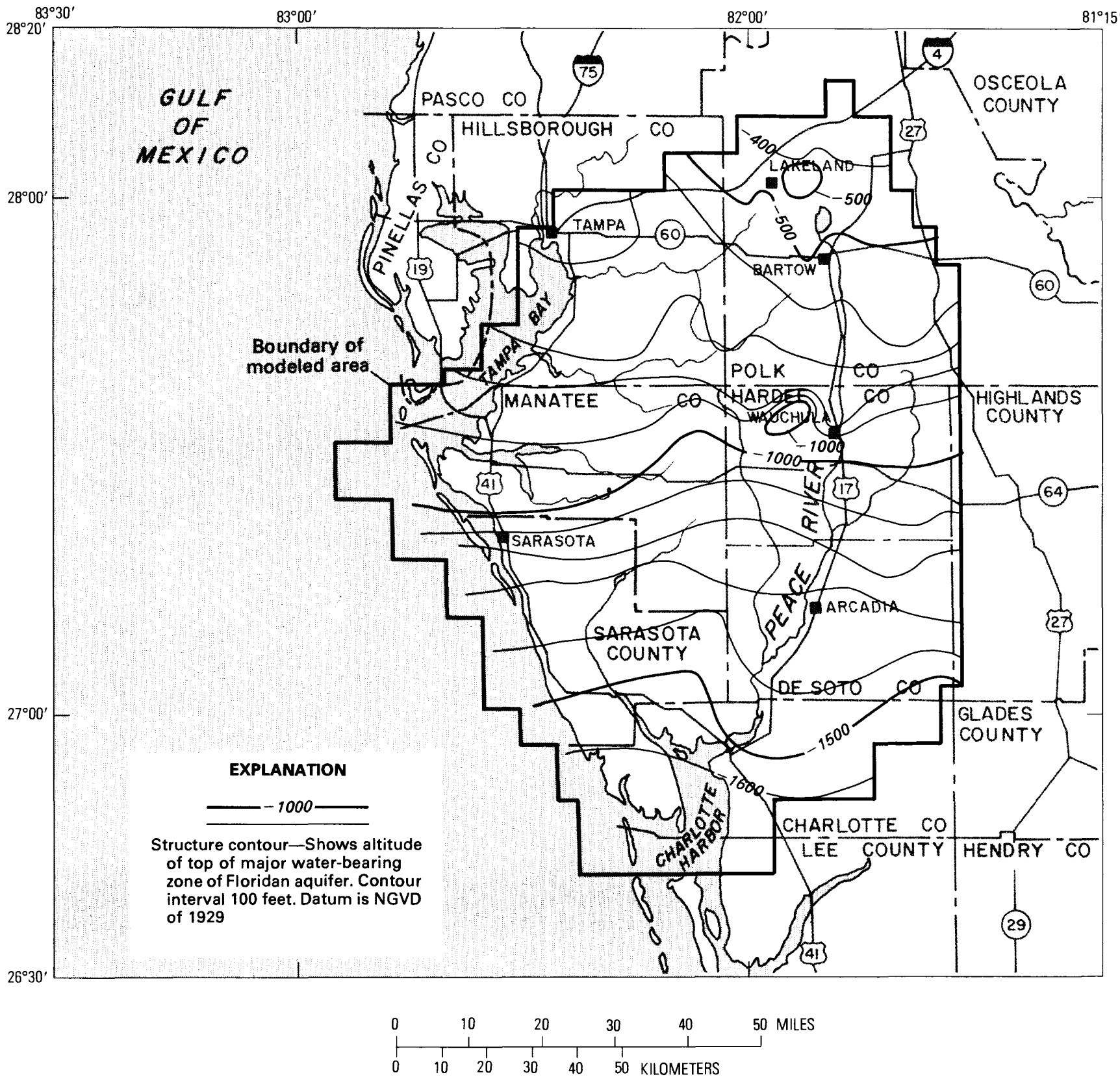

Figure 3. Altitude of top of major water-bearıng zone of the Floridan aquifer.

The map in figure 7 is highly generalized and serves principally to direct attention to broad areas in which to best evaluate changes in the movement of saltwater or water in the zone of transition in response to changes in the potentiometric surface. The generalized nature of the map is in part due to the sparseness of reliable data and in part due to the complexity of distribution of chloride concentrations in the aquifer.
Data

Figure 7 is based on information contained in published reports and in the water-quality data files of the U.S. Geological Survey. Information in reports by Kaufman and Dion $(1967 ; 1968)$, Sutcliffe (1975), and Wilson (1977b) was used in mapping the southern part of the modeled area. D. P. Brown and J. D. Fretwell 

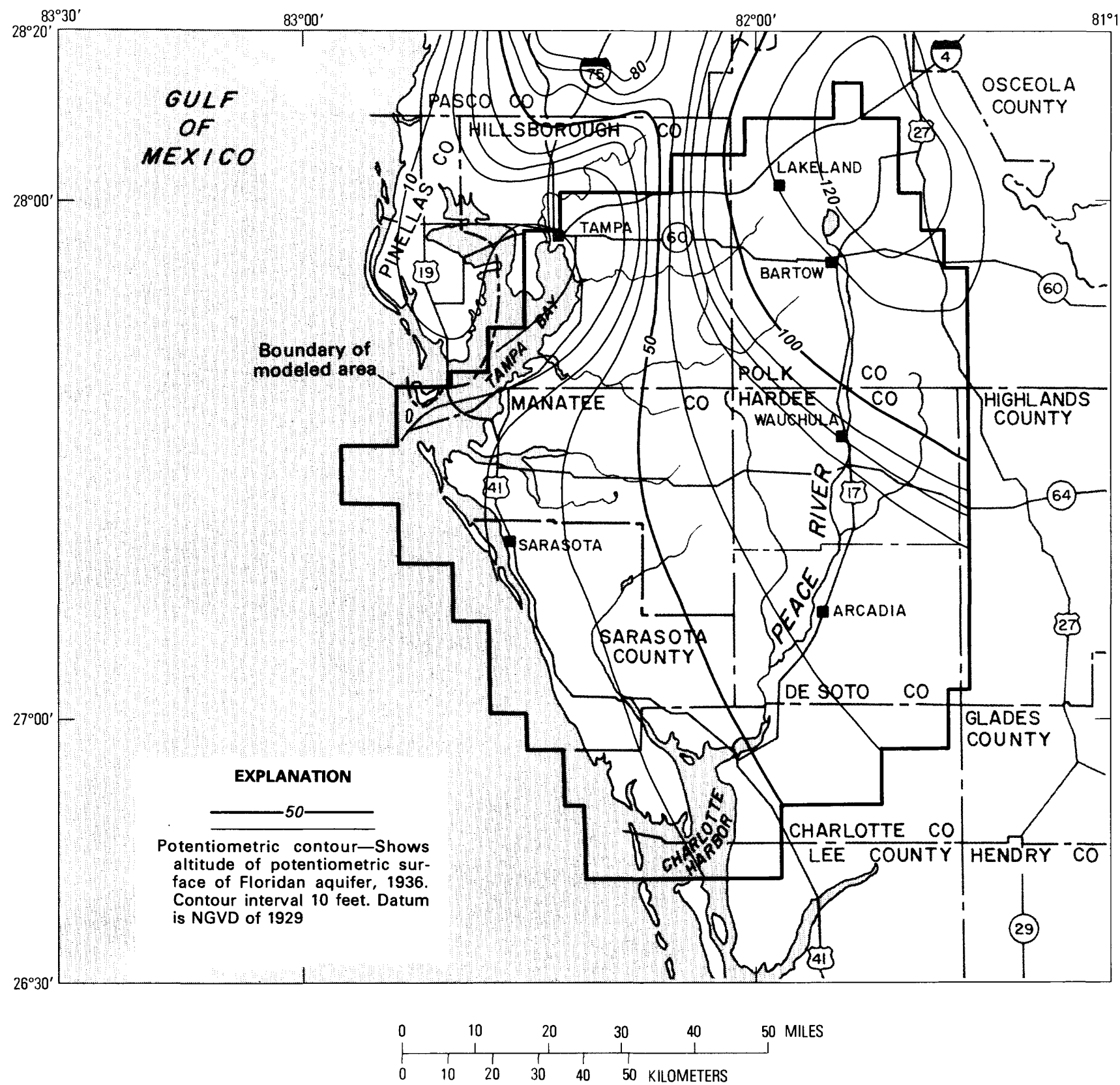

Figure 4. Potentiometric surface of the Floridan aquifer under predevelopment conditions

(written communs., June 1979) provided data for Sarasota, Manatee, and Hillsborough Counties.

On the basis of the amount of data, the freshwater boundary of the zone of transition is mapped more reliably than is the saltwater front. Hundreds of analyses are available from inland wells that tap the highly transmissive zone in the Avon Park Limestone, whereas only a few wells tap this zone in coastal areas. The posi- tion of the saltwater front in the upper part of the aquifer presumably occurs somewhere offshore. However, field data do not exist to determine its position.

Samples analyzed from wells open to discrete zones in the lower part of the Floridan aquifer provided the most reliable data for figure 7. Most samples, however, were from wells open from the top of the aquifer to the major water-bearing zone in the lower part of the 

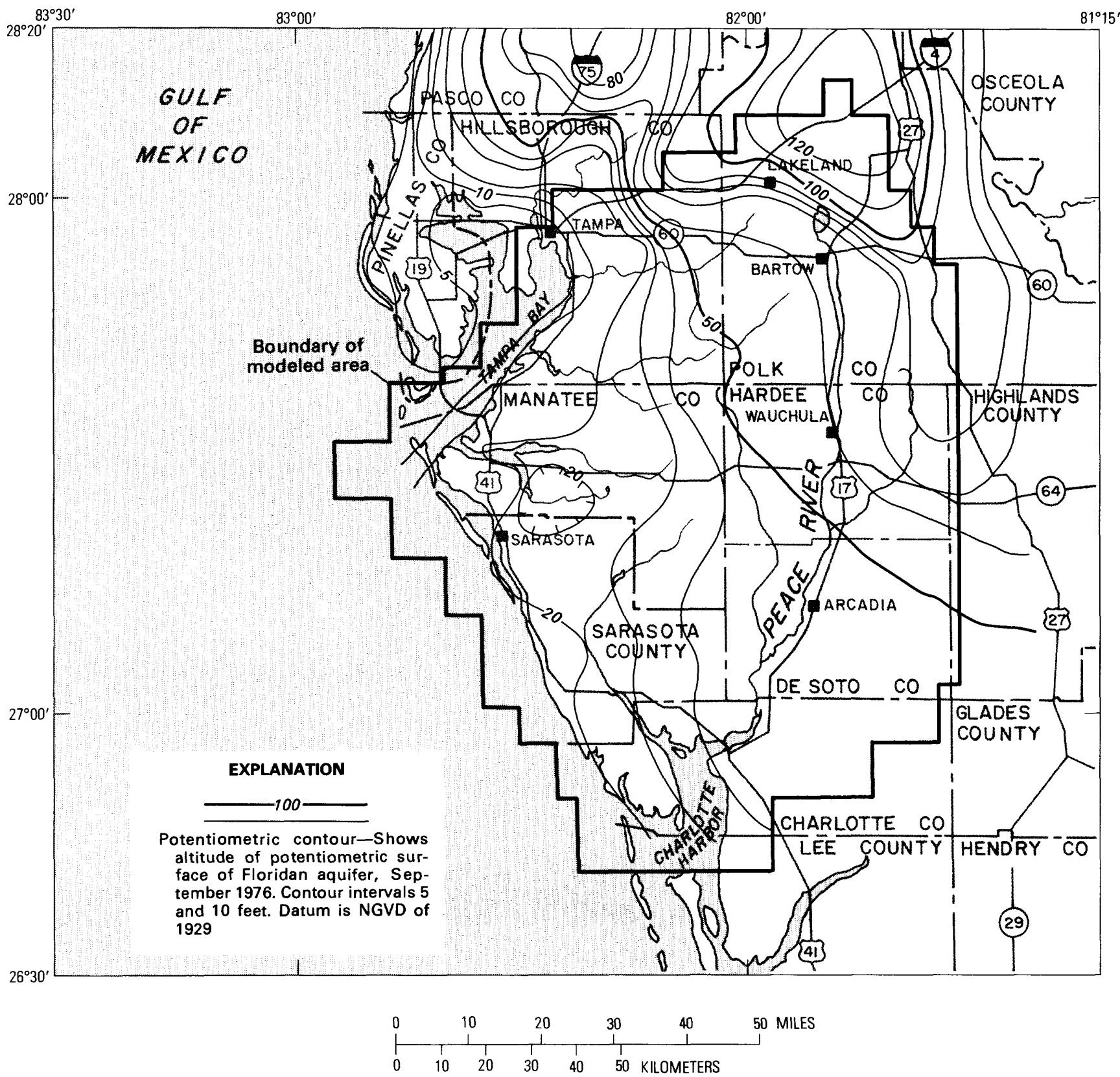

Figure 5. Potentiometric surface of the Floridan aquifer, September 1976.

aquifer, although generally not to the base of the aquifer. Samples from these wells represent a blend of water from multiple permeable zones. Because the lower part of the aquifer contains the most highly transmissive zone, that section yields the most water to wells. Therefore, the blended samples were also used as guides to determining the chloride distribution in the lower part of the aquifer.

Most water-quality data used in the preparation of figure 7 were not time synchronous, and the map, therefore, does not represent conditions at any specific time. However, no major regional changes in chloride concentration are known to have occcurred in the modeled area during the 1960's and 1970's (Geraghty and Miller, Inc., Reynolds, Smith and Hill, 1977), and the map is indicative of generalized conditions during 1960-80.

\section{Complexity}

Many factors contribute to the complexity of the distribution of chloride concentration in the Floridan 

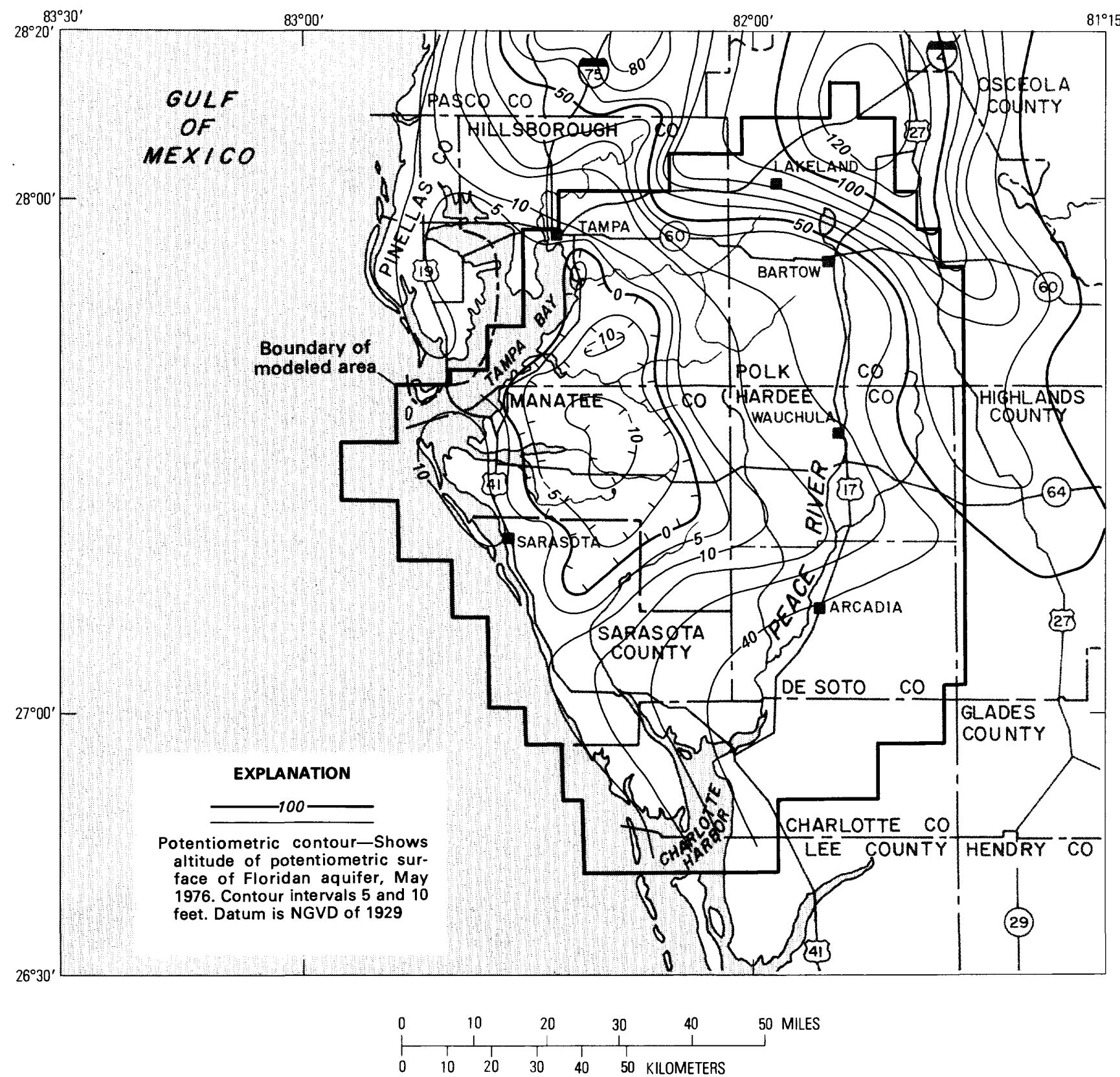

Figure 6. Potentiometric surface of the Floridan aquifer, May 1976.

aquifer within the zone of transition. Layering in an aquifer, such as in the Floridan aquifer, tends to broaden the zone of transition (Cooper, 1964, p. C10) and tends to result in vertical variability in chloride concentration. Thus, because of differences in permeability among layers, some parts of a vertical section may contain either saltwater or "background water", and others may contain transition water with a wide range of chloride concentrations.

During the past few hundreds of thousands of years, the region has been subjected to multiple cycles of sea-level fluctuations. The present-day chloride distribution may therefore reflect, in part, the lagging and overlapping effects of past sequences of intrusion and flushing of saltwater due to sea-level changes.

Ground water with chloride concentrations greater than background values may have multiple sources, including laterally intruded saltwater, residual connate water (water of deposition), or salty ground water leaking upward through the lower confining bed or from deeper parts of the aquifer. In parts of Charlotte and Sarasota Counties, high-chloride ground water has 

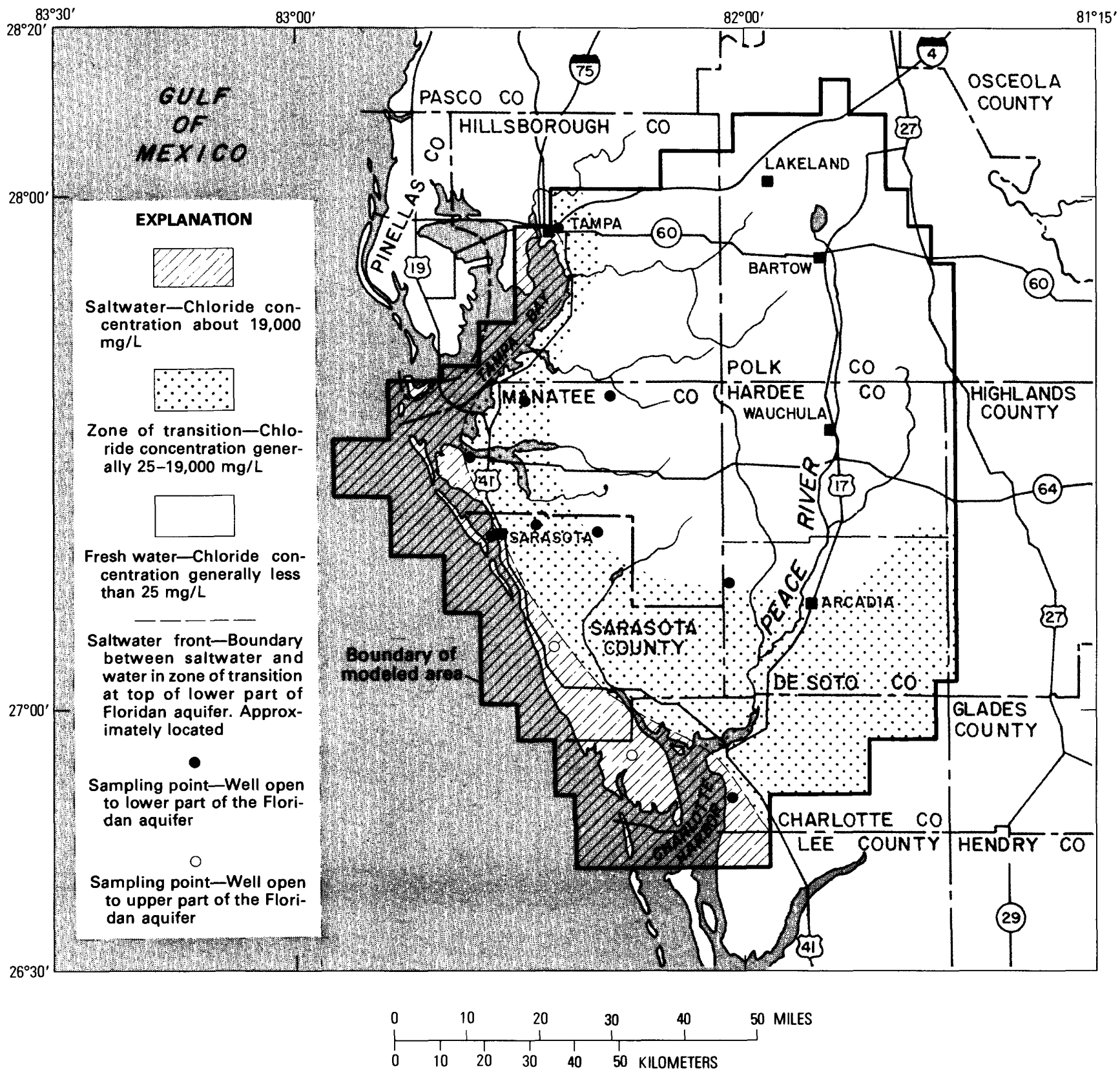

Figure 7. Chloride concentration in the lower part of the Floridan aquifer.

moved up boreholes of abandoned irrigation wells from deep aquifer zones of higher head into shallow zones with lower head (Sutcliffe, H., Jr., 1975; written commun., 1979).

The zone of transition was defined on the basis of chloride concentration alone. In some parts of the zone of transition and farther inland, water in the lower part of the Floridan aquifer has relatively low chloride concentrations, but relatively high sulfate concentrations. An effort was not made in this investigation to map or evaluate the movement of water with high sulfate concentrations.

\section{Saltwater-Freshwater Interface}

The existence of a zone of transition between saltwater and fresh "background water" precludes the existence of a sharp interface separating saltwater and fresh water. The theoretical equilibrium position of such an interface was computed, however, as an aid in estimating long-term effects of changes in the potentiometric surface on the saltwater distribution. Fig-ure 8 shows the approximate positions of the intersection of the theoretical interface with the top and base of the lower part of the Floridan aquifer. 
Interface altitudes were calculated using the Ghyben-Herzberg formula (Domenico, 1972), assuming a freshwater density of 1.000 and a saltwater density of 1.025. With these densities, the depth to the theoretical interface below sea level is 40 times the height of the freshwater head above sea level. Freshwater heads were obtained from the predevelopment potentiometric-surface map (fig. 4). A contour map of the interface was superimposed on the structure contour map of the top of the lower part of the Floridan aquifer (fig. 3). A point was plotted wherever a contour line on the interface map intersected a contour line representing the same altitude on the aquifer map. Connecting the points gave the trace of the line formed by the intersection of the two surfaces. A similar procedure was followed with the interface map and the structure contour map of the base of the Floridan aquifer (fig. 2). The two traces are shown in figure 8 .

Use of the Ghyben-Herzberg principle provides an approximation rather than a direct solution of the interface position because field conditions and available data do not fully satisfy the assumptions implicit in the application of the principle. The method assumes hydrostatic conditions, whereas, the system in west-central Florida is dynamic, commonly with vertical components of flow. More precise expressions for the interface position in a dynamic system were given by Hubbert (1940) and Lusczynski (1961), but these require knowledge of saltwater heads and head losses between points at different aquifer depths. The magnitude and significance of these parameters are generally unknown in the area.

The Ghyben-Herzberg method also assumes that the potentiometric heads used in computations are equivalent to freshwater heads at the interface. Potentiometric-surface maps of west-central Florida, used to obtain values of head, are based on measurements in wells having different depths and lengths of open hole in the freshwater part of the aquifer. Thus, the mapped surface represents an approximation of integrated values of freshwater head. Where upward components of flow exist in the system, as in the coastal discharge areas, potentiometric head increases with depth. Thus, the integrated values of head may be considerably less than freshwater heads at the interface. Because of these factors, application of the Ghyben-Herzberg method generally results in computed depths to the interface that are too shallow. Thus, the method gives cautious results.

Figure 8 shows that at the top of the lower part of the aquifer the computed interface position corresponds approximately with the observed position of the saltwater front. Water-quality data are not sufficiently available to map the position of the saltwater front at the base of the aquifer (that is, the "toe" of the front). However, the "toe" position is inferred to be approxi- mately the same as the computed interface position at the aquifer base (fig. 8), on the basis of the general correspondence of the front and interface at the top of the lower part of the aquifer. The inferred position of the "toe" is also generally compatible with available waterquality information. Figure 9 shows schematically the relationships between the theoretical equilibrium interface and the observed chloride distribution.

The correspondence of the mapped saltwater front and the equilibrium position computed from predevelopment potentiometric heads (figs. 8, 9) suggest that the front may have reached equilibrium under predevelopment conditions, but has not yet adjusted to pumping stresses caused by modern development. The relationship between the position of the front and the computed equilibrium position may be coincidental, however, for little is known about the long-term or recent history of movement of the front.

\section{GROUND-WATER WITHDRAWALS}

The Floridan aquifer is the major source of water supply in most of the modeled area. Withdrawals from this aquifer averaged about $649 \mathrm{Mgal} / \mathrm{d}$ in 1975, and withdrawals were expected to increase to about 842 Mgal/d in 2000 (Wilson and Gerhart, 1979a). Withdrawals for industrial, public supply, and agricultural purposes for 1975 and projections to 1985 and 2000 are summarized in figure 10 . These withdrawal rates served as a basis for simulating changes in the potentiometric surface.

In 1975, more than half (174 Mgal/d) of the industrial ground-water withdrawals were for phosphate mines, nearly all of which were in Polk County. Mines existing in Polk County in 1976 are expected to be phased out, and mines are expected to begin operations in DeSoto, Hardee, and Manatee Counties in the decades ahead. Projected withdrawal rates for phosphate mines were $217 \mathrm{Mgal} / \mathrm{d}$ in 1985 and $161 \mathrm{Mgal} / \mathrm{d}$ in 2000. Projected withdrawal rates for phosphate chemical plants are expected to remain relatively constant ${ }^{1}$, at about $128 \mathrm{Mgal} / \mathrm{d}$. The locations of the plant are also expected to remain constant, with the ore being shipped to existing chemical plant locations. Withdrawal rates for other self-supplied industries were expected to remain unchanged at about $26 \mathrm{Mgal} / \mathrm{d}$.

In 1975 about $50 \mathrm{Mgal} / \mathrm{d}$ was withdrawn for municipal supplies. Rates were projected to be about 108 $\mathrm{Mgal} / \mathrm{d}$ in 1985 and to be about $145 \mathrm{Mgal} / \mathrm{d}$ in 2000, owing to expansion of existing well fields and development of new well fields.

' $128 \mathrm{Mgal} / \mathrm{d}$ is given as the value for probable withdrawals for phosphate chemical plants for the years 1975, 1985, and 2000 in Professional Paper 1217 (in press). Variations resulting from multiplying percent times total in figure 10 (this report) are due to rounding of percent values. 

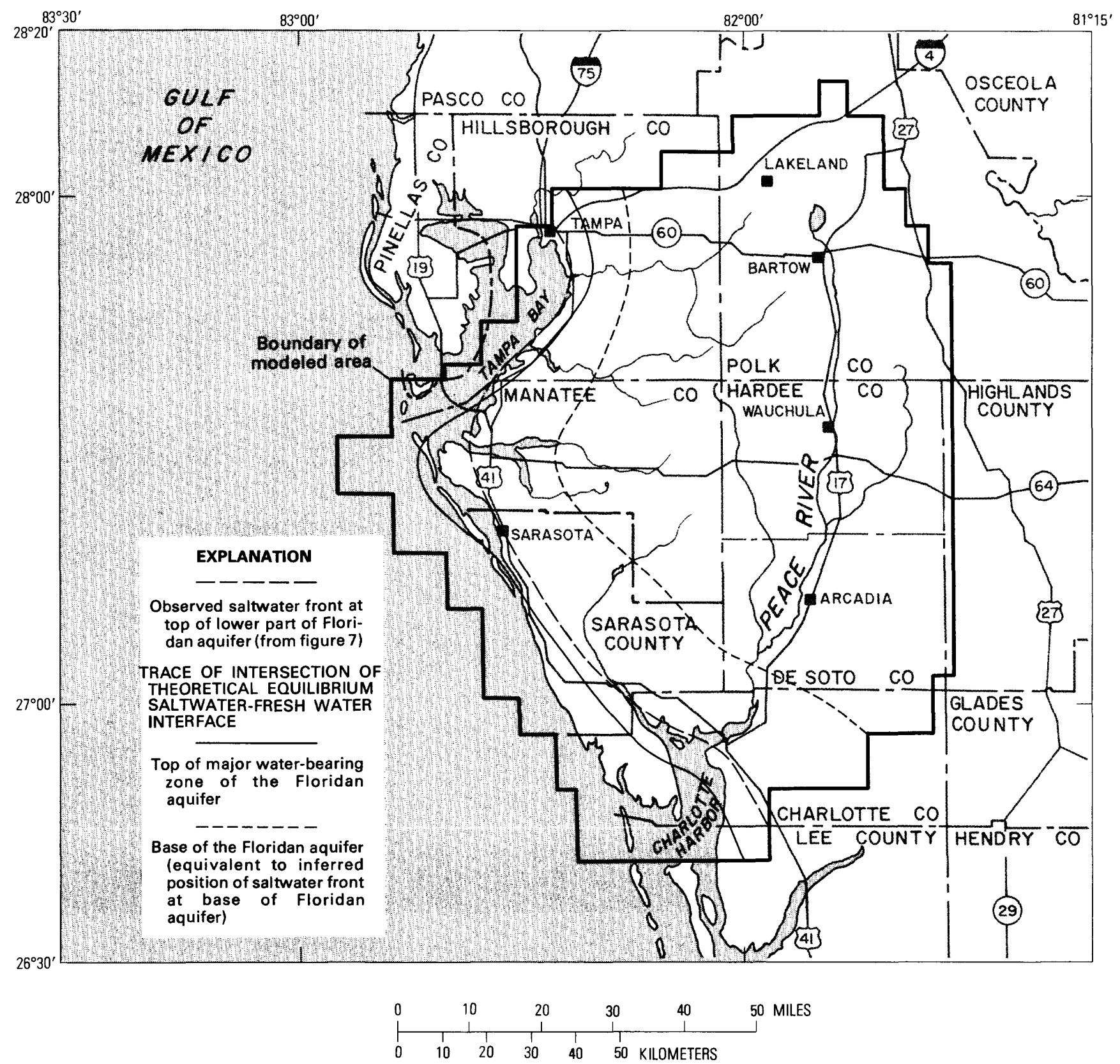

Figure 8. Theoretical equilibrium position of saltwater-freshwater interface under predevelopment conditions.

The largest single use of ground water is for irrigation of crops, principally citrus trees, vegetables, and pasture. In 1975-76, irrigation withdrawals averaged about $271 \mathrm{Mgal} / \mathrm{d}$ (fig. 10). Unlike those for other major uses, withdrawals for irrigation are highly seasonal; during the rainy summer months, withdrawals are practically nonexistent. The 1975-76 values were based on an inventory of irrigation conducted during phase I of this investigation.

\section{SIMULATED POTENTIOMETRIC SURFACE}

\section{Ground-Water Flow Model}

The calibrated transient model described by Wilson and Gerhart (1979a) was used to simulate changes in the potentiometric surface of the Floridan aquifer during 1976-2000. The model utilizes a finite-difference method in which differential equations describing ground-water flow are solved numerically. The equa- 


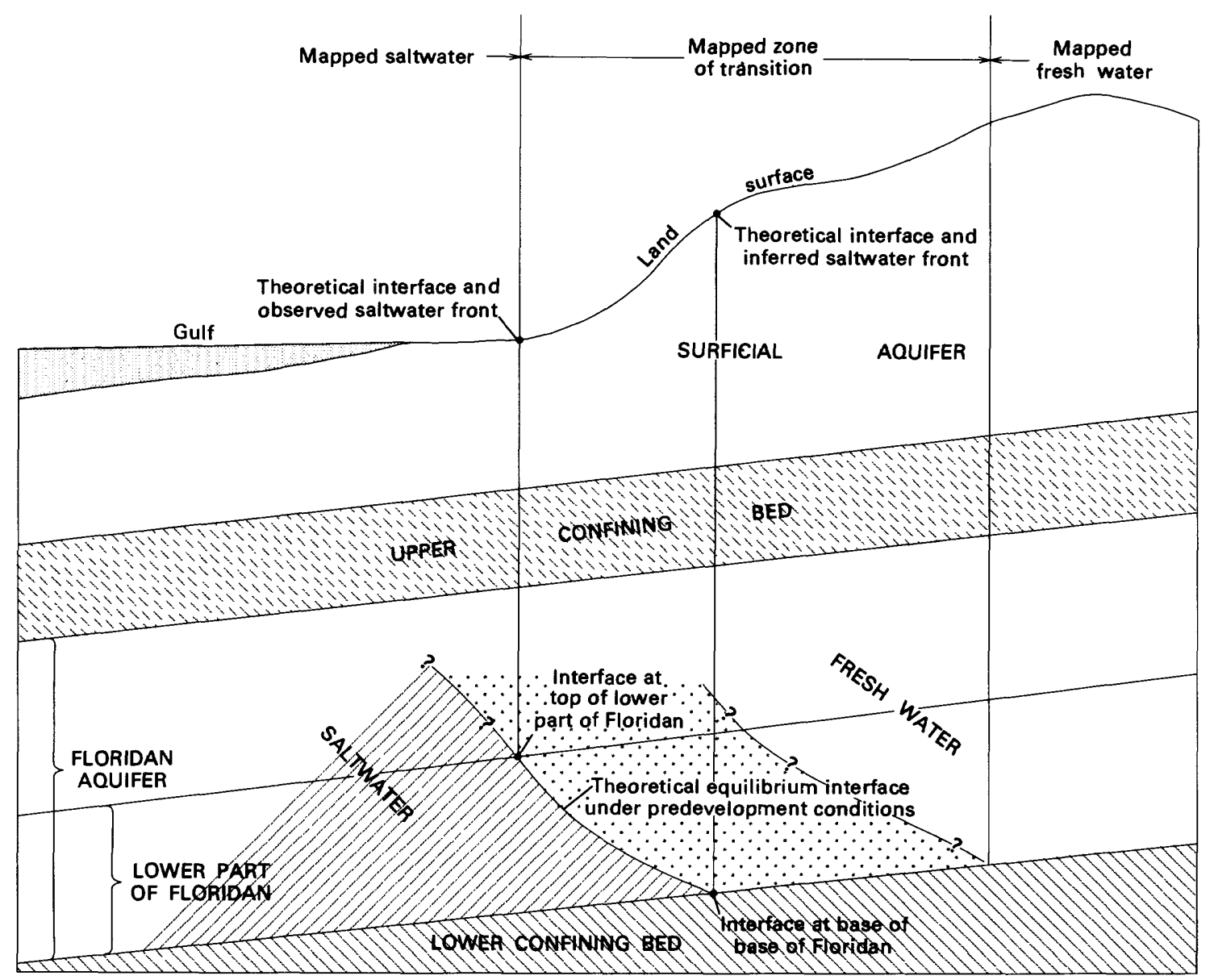

Figure 9. Conceptual view of relationships between theoretical predevelopment equilibrium interface and observed chloride distribution in lower part of the Floridan aquifer.

tions require that hydraulic properties, boundaries, and stresses be defined for the area modeled. The digital model of two-dimensional flow was described by Trescott, Pinder, and Larson (1976); input parameters for the model were described by Wilson and Gerhart (1979a).

Major assumptions made in the model analysis of ground-water flow are as follows:

1. Ground water moves horizontally in the Floridan aquifer in a single-layer, isotropic medium.

2. Water moves vertically into or out of the Floridan aquifer through the upper confining bed. No leakage occurs through the lower confining bed.

3. The head in the surficial aquifer does not change in response to imposed stress.

4. Movement of saltwater is assumed to have little or no effect on calculated freshwater heads.
The ground-water flow system, as modeled, is shown schematically in figure 11 . Regionally, the system approximates the assumed conditions, although locally, deviations occur. Most wells are finished as open holes and tap most of the thickness of the Floridan aquifer. A confining bed overlies the Floridan aquifer throughout the area, and natural aquifer discharge and recharge occur principally as vertical leakage through this confining bed. Aquifer tests have shown the lower confining bed to be relatively impermeable. The seasonal range of fluctuation of the water table in the surficial aquifer is generally less than 5 feet, and in most of the study area the water table is little affected by withdrawals from the Floridan aquifer.

The model oversimplifies a complex system. The model is inadequate to simulate vertical flow components in recharge and discharge areas and does not account for multiple zonation of the Floridan aquifer. Some errors remaining in the calibrated model are due to these inadequacies. Nonetheless, the model used was 


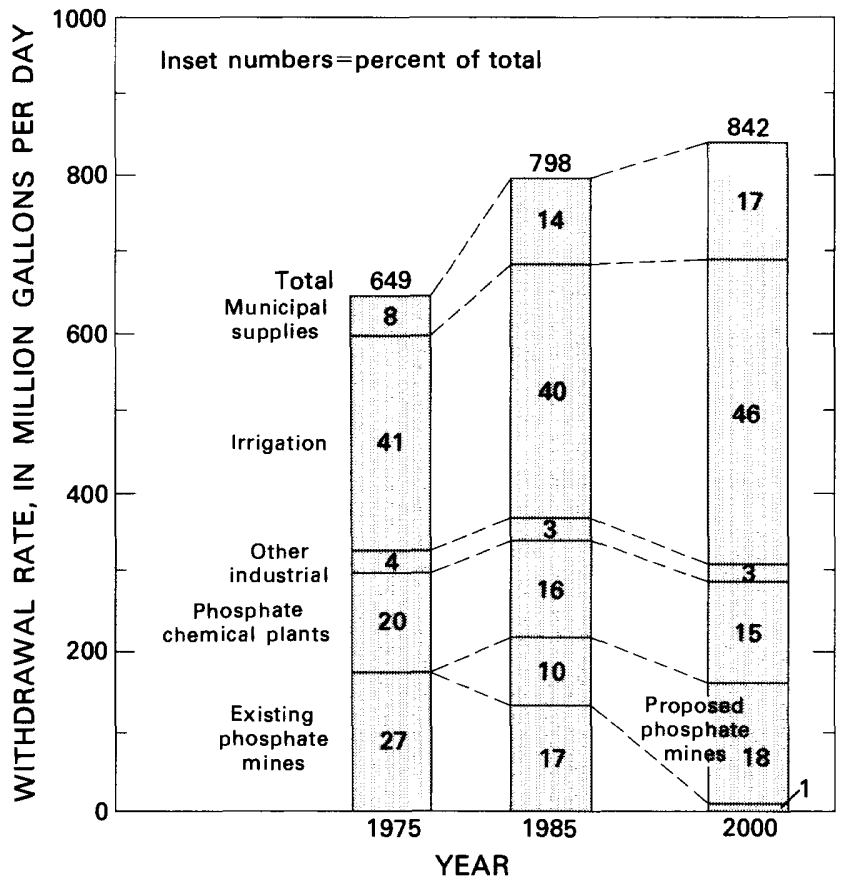

Figure 10. Ground-water withdrawal rates for 1975 and projections for 1985 and 2000

the most appropriate one available at the time the investigation began, considering the size of study area, objectives of the investigation, and state of knowledge of the hydrogeology.

A head-controlled flux boundary condition was utilized for all lateral model boundaries during simulations. The two-dimensional flow model described by Trescott, Pinder, and Larson (1976) was modified to include this boundary condition, as described by Wilson and Gerhart (1979a).

\section{Results}

Simulated changes in the potentiometric surface of the Floridan aquifer were based on projected combined ground-water withdrawals for irrigation, municipal supplies, existing and proposed phosphate mines, phosphate chemical plants, and other industrial uses for 1976-2000. All input parameters, including the magnitude and timing of withdrawal rates, are identical to those given in the report for phase 1 of this investigation. (See Wilson and Gerhart, 1979a.) In that report, head changes were simulated for May 1976 to May 2000 and for November 1976 to October 2000. In the model runs, each year was simulated by using two pumping periods per year; one run represented an irrigation season, and the other represented a non-irrigation season. The results are repeated in this report to aid in evaluating the effects of changes in the saltwater front.
Figure 12 shows simulated changes in potentiometric surface resulting from the combined projected withdrawals for irrigation, municipal supplies, existing and proposed phosphate mines, phosphate chemical plants, and other industrial uses for May 1976 to May 2000 . The map shows about 10 feet of rise in southwestern Polk County and about 35 feet of decline in parts of Manatee and Hardee Counties. A decline of more than 5 feet is shown along almost the entire coastal area.

Simulated changes for May 1976 to May 2000 (fig. 12) were superimposed on the May 1976 potentiometric-surface map (fig. 6) to obtain a map of the simulated potentiometric surface for May 2000, as shown in figure 13. The principal change between the potentiometric-surface map of May 1976 and that of May 2000 is a broadening, deepening, and eastward shift of the major cone of depression. In May 2000, the lowest level of this cone of depression is projected to be more than 30 feet below sea level, and the sea-level (zero) potentiometric contour line extends eastward to the Peace River in Hardee County. The potentiometric surface is also projected to be below sea level along a part of coastal Sarasota County.

Simulated changes resulting from the combined effects of pumping from November 1976 to October 2000 are shown in figure 14 . The pattern of change is similar to that shown in the May 1976-May 2000 change map (fig. 12), with a rise in the potentiometric surface in parts of Polk County and declines elsewhere. From November 1976 to October 2000 maximum rise is about 15 feet, and maximum decline is about 25 feet (fig. 14).

Simulated changes for November 1976 to October 2000 (fig. 14) were superimposed on the September 1976 potentiometric-surface map (fig. 5) to obtain a map of the simulated potentiometric surface for October 2000 , as shown in figure 15. Compared to the September 1976 potentiometric-surface map, the October 2000 map shows an eastward shift of the $20-, 30-$, and 40-foot contour lines and a reentrant 10-foot line in eastern Manatee County, reflecting a remnant of the closed depression shown in May 2000. The rise in the potentiometric surface in Polk County is reflected by a southward shift of the 60- and 70-foot contour lines compared to September 1976 conditions.

\section{ESTIMATED MOVEMENT OF SALTWATER FRONT}

The effects of projected ground-water pumpage on movement of the saltwater front in the lower part of the Floridan aquifer were estimated based on changes in potentiometric gradient between 1976 and 2000.

In both 1976 and 2000, gradients of the potentiometric surface near the saltwater front are landward in the spring and coastward in the fatl. Projected ground- 


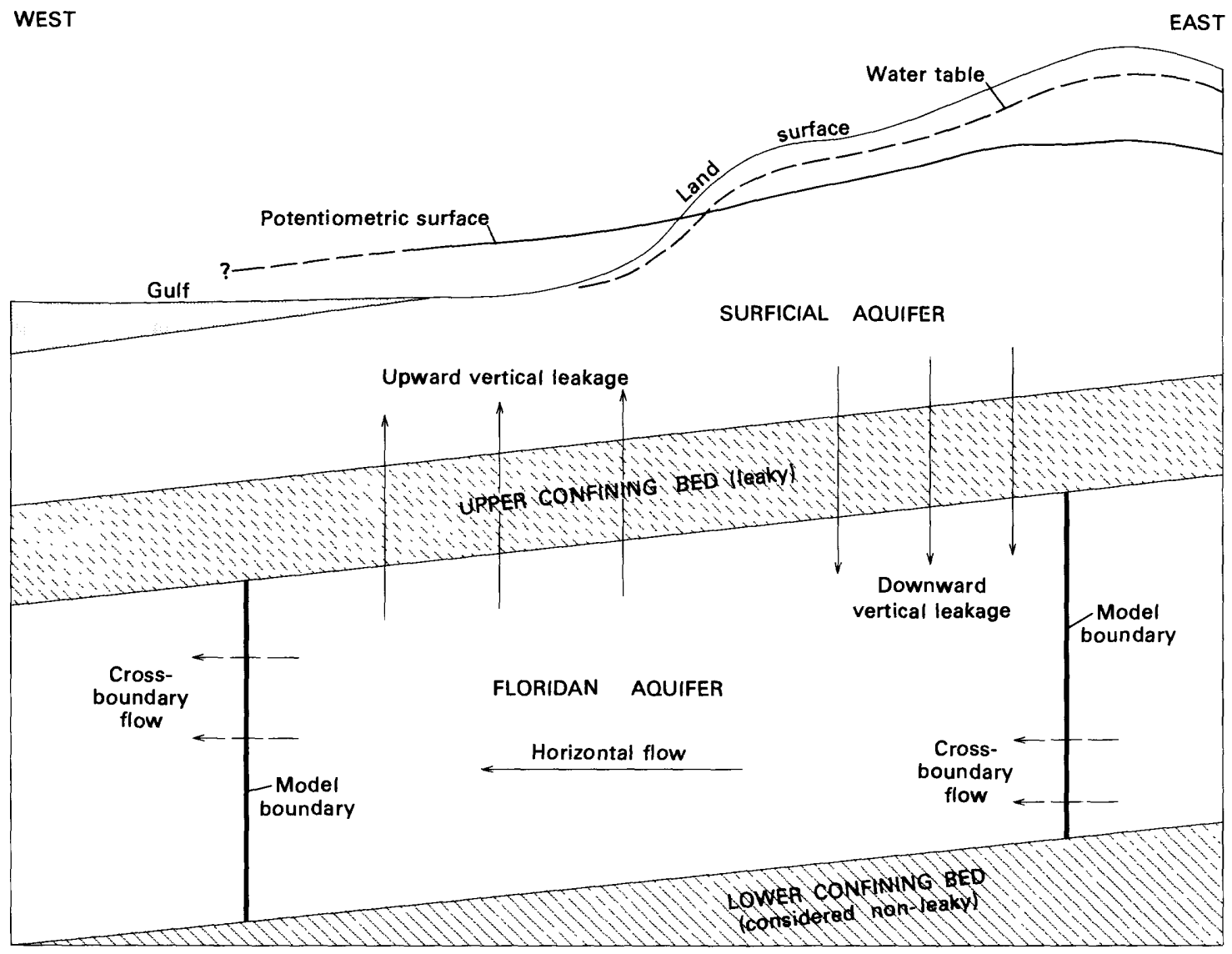

Figure 11. Generalized conceptual model of steady-state flow.

water withdrawals in the modeled area during 1976-2000 are expected to result in an increase in the landward gradient in the spring and a decrease in the coastward gradient in the fall. These changes in gradients correspond to changes in ground-water flow rates. When ground-water flow near the saltwater front is landward, an increase in flow rate can be equated directly to an increase in rate of movement of the front. When ground-water flow near the front is coastward, changes in rates of movement of the front are dependent on other factors in addition to changes in ground-water flow rates (Cooper, 1964). Thus, in the analyses, rates of flow were computed from potentiometric gradients for May 1976 and May 2000 to estimate the amount of change in the rates of inland movement of the saltwater front under spring conditions. However, the decrease in potentiometric gradient between November 1976 and October 2000 was determined only to indicate that some net inland movement of the front could occur under fall conditions.

\section{Spring Conditions}

The mapped position of the saltwater front (fig. 7 ) is within the regional cone of depression shown in the potentiometric-surface maps for May 1976 (fig. 6) and May 2000 (fig. 13) in parts of Hillsborough, Manatee, and Sarasota Counties. To estimate and compare rates of landward ground-water flow at the saltwater front at these two times, velocities were calculated along three sections, one each in Hillsborough, Manatee, and Sarasota Counties (fig. 16). Velocity was computed as follows, and results are shown in table 2:

$$
\begin{aligned}
v & =\frac{T I}{b \Theta} \\
& =\frac{K I}{\Theta}
\end{aligned}
$$

where $\quad v=$ ground-water velocity, in feet per day;

$T=$ aquifer transmissivity, in feet squared per day;

$I=$ potentiometric gradient, in feet per foot;

$b=$ aquifer thickness, in feet;

$\Theta=$ aquifer porosity, dimensionless, and

$K=$ aquifer hydraulic conductivity $(T / \mathrm{b})$, in feet per day. 

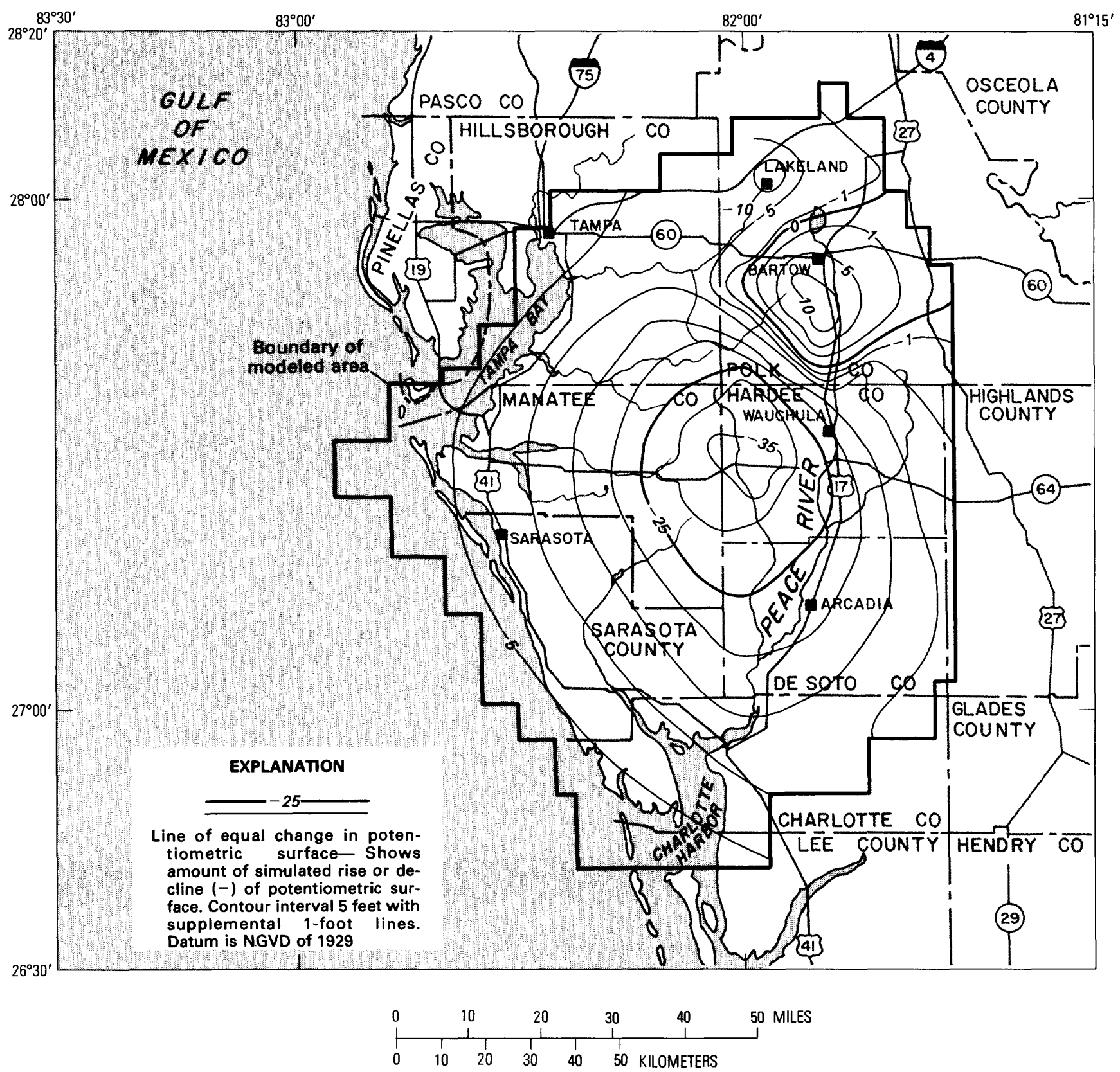

Figure 12. Simulated changes in potentiometric surface due to projected ground-water withdrawals, May $1976-$ May 2000 .

The three sections were drawn landward from the saltwater front along flow lines on the May 1976 and May 2000 potentiometric-surface maps (figs. 6, 13). Common sections could be used for both times because orientation of the contour lines near the front is approximately the same on both maps, and because the potentiometric contour lines are mostly parallel to the front.

Aquifer transmissivity is $120,000 \mathrm{ft} / \mathrm{d}$ at all sections, according to the map of modeled transmissivity of Wilson and Gerhart (1979a, fig. 8). Gradients along the sections were determined directly from the May po- tentiometric-surface maps. For purposes of analysis, aquifer thickness was assumed to be equivalent to the thickness of the lower part of the Floridan aquifer measured from the top of the major water-bearing zone to the base of the aquifer. An average thickness along each section was determined from figures 2 and 3. An average porosity of 0.2 was used, based on the approximate average porosity for the dolomite section at Pinellas County test-injection sites (J. J. Hickey, written commun., 1979). 

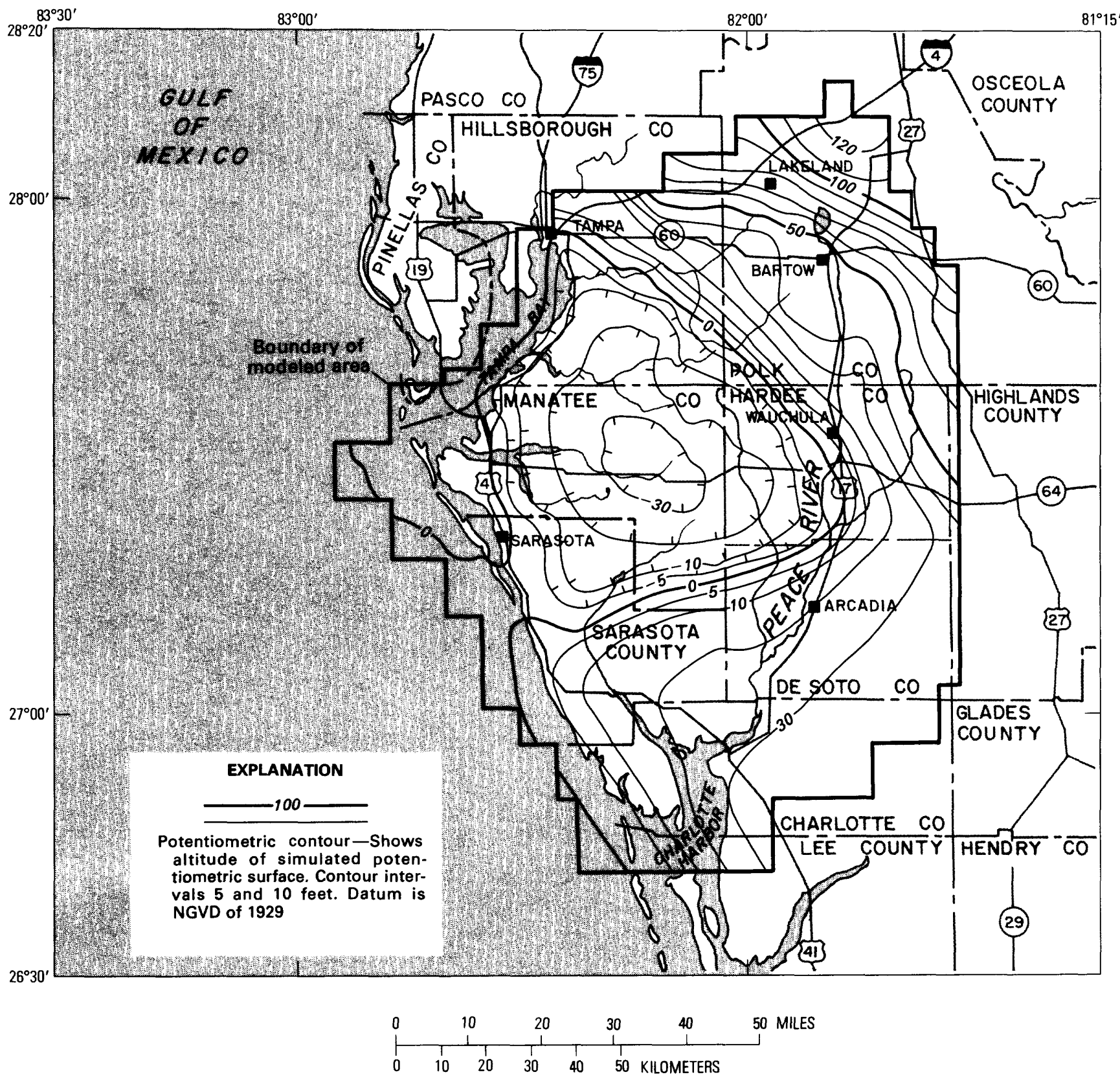

Figure 13. Simulated potentiometric surface, May 2000

Table 2 shows that velocities are similar along the three sections in 1976 and in 2000 . Average velocity in May 1976 was $0.30 \mathrm{ft} / \mathrm{d}$; average velocity for May 2000 is projected to be $0.36 \mathrm{ft} / \mathrm{d}$, or a 20 percent increase. The higher flow rate in 2000 reflects the steepening of the gradient resulting from the increased pumping between 1976 and 2000.

Distances that ground water would move at the computed May 1976 and May 2000 flow rates are shown for various lengths of time in figure 17. An average of the two flow rates is shown by a dashed line. Because the gradient is landward, it can be assumed that movement of the saltwater front is directly related to the flow of ground water at the front. Figure 17 can be used to estimate the amount of movement. For example, after 10 years the front would have moved about 1,100 feet at the May 1976 rate, about 1,300 feet at the May 2000 rate, and about 1,200 feet at the average rate $(0.33 \mathrm{ft} / \mathrm{d})$. If the average of the May 1976 and May 2000 flow rates were to persist continuously for 24 years (for example, during 1976-2000), the front would move landward about 2,900 feet, or slightly more than half a mile. More 

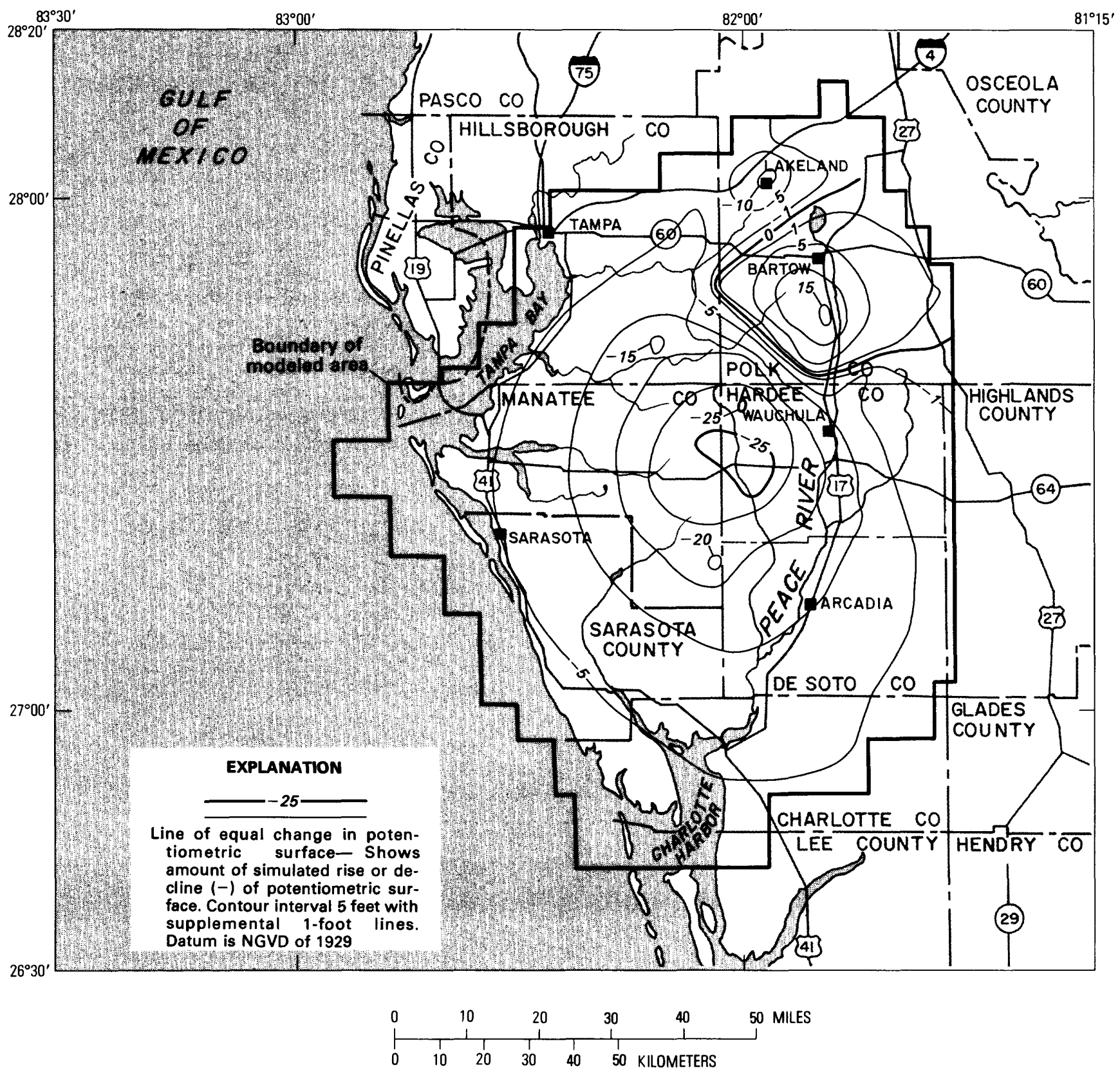

Figure 14. Simulated changes in potentiometric surface due to projected ground-water withdrawals, November 1976October 2000.

than two centuries (about 220 years) would be required for the front to move 5 miles at the average rate.

\section{Fall Conditions}

Flow rates and flow directions that occur in May do not persist throughout a year. In fact, the landward potentiometric gradient of May is reversed and becomes seaward in the summer and fall. Maps of the observed
September 1976 potentiometric surface (fig. 5) and simulated October 2000 surface (fig. 15) were compared to determine if changes in gradient occurred under fall conditions. 1n both maps, the gradient at the saltwater front is toward the coast. However, the configurations of the two potentiometric surfaces are sufficiently different that an average change in gradient near the saltwater front was determined from the change-in-head map (fig. 14), rather than from selected sections com- 

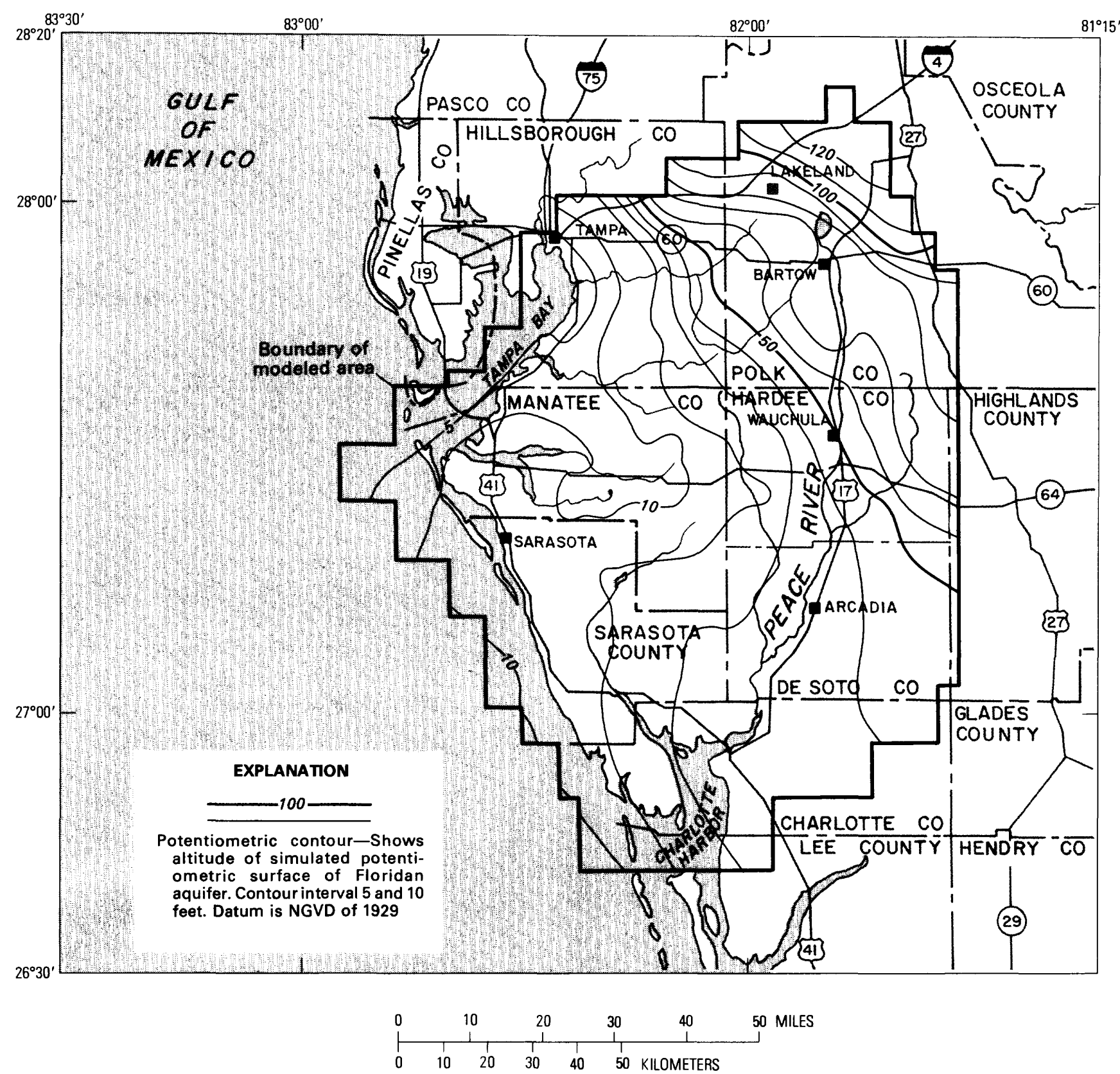

Figure 15. Simulated potentiometric surface, October 2000.

mon to the two potentiometric-surface maps. The computed average seaward freshwater gradient along the saltwater front decreased by about $8.8 \times 10^{-5} \mathrm{ft} / \mathrm{ft}$ from November 1976 to October 2000. This compares to an average increase in landward gradient of about $6.9 \times 10^{-5} \mathrm{ft} / \mathrm{ft}$ from May 1976 to May 2000 .

The effects of the decrease in coastward potentiometric gradient between November 1976 and October 2000 are more difficult to assess than the effects of the increase in landward potentiometric gradient between May 1976 and May 2000. In May, the increased land- ward gradient is a direct measure of increased rate of landward flow of saltwater. In the fall, however, a reduction in coastward gradient would result in a reduced rate of fresh ground-water flow toward the saltwater front. If other factors were constant, the front would move landward. Whether this would actually occur, and if so at what rate, is unknown, because the effect is also dependent upon changes in freshwater discharge, both by upward leakage through the upper confining bed and by pumping. These complex relationships were not evaluated in this analysis. 

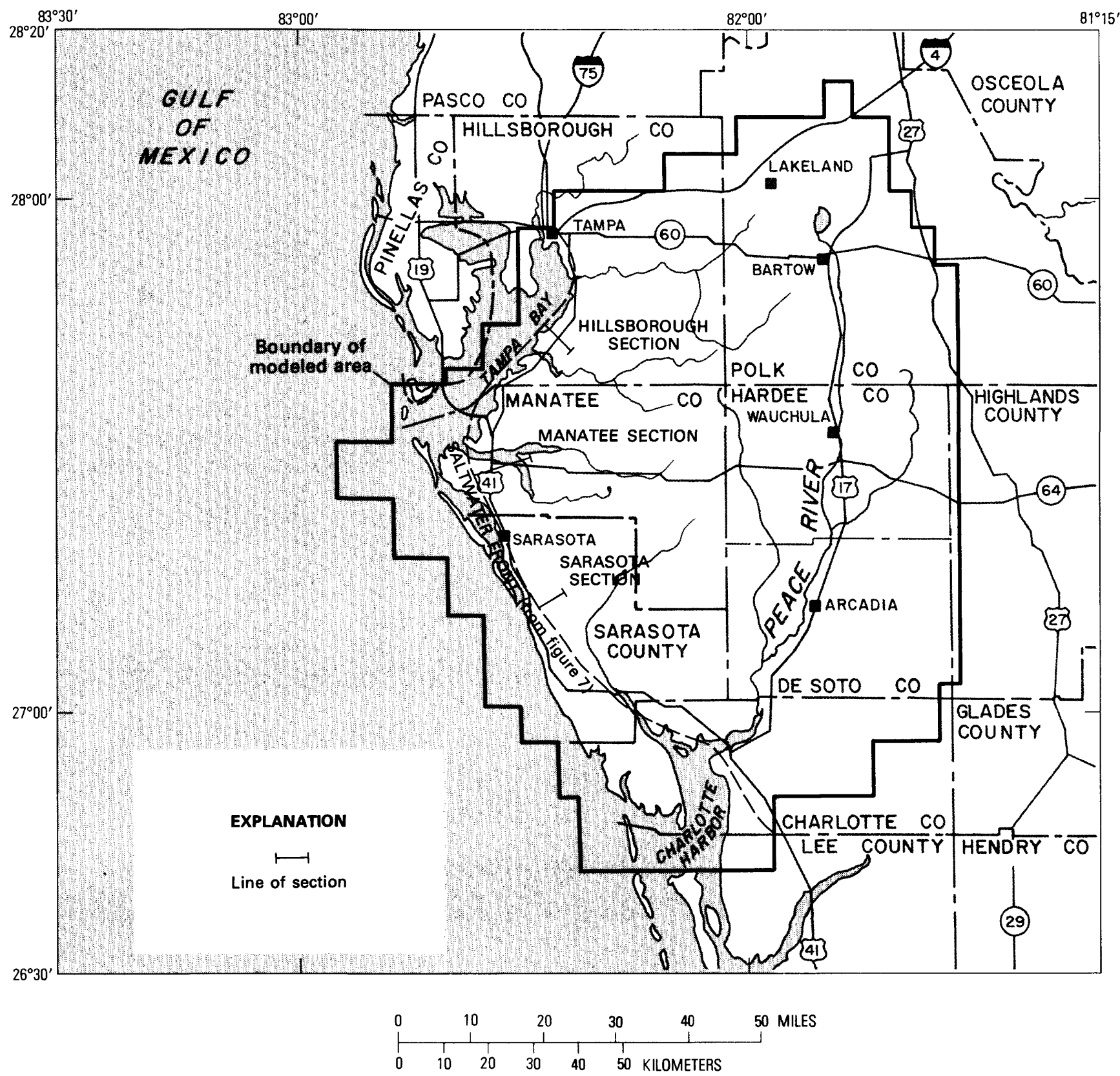

Figure 16. Sections used to calculate ground-water flow velocity.

\section{Discussion}

The computed flow rates are affected by a variety of factors that could impact on conclusions that might be drawn from the analyses. Most factors discussed below tend to make the computed results extreme, resulting in a "worst case" approach. That is, computed rates of flow and the resulting computed amounts of landward movement of the saltwater front are probably greater than those that would actually occur under the projected pumpage.
Computed average May 1976 and May 2000 flow rates (table 2) may be high because the porosity $(0.20)$ used in the computations may be low, and the hydraulic conductivity $(185 \mathrm{ft} / \mathrm{d})$ may be high. Data from J. J. Hickey (written commun., 1979) gave an average porosity of about 0.26 for the Floridan aquifer at Pinellas County test-injection sites, based on determinations made from geophysical logs. The limestone portion of the section had an average porosity of about 0.31 , and the dolomite portion had an average porosity of about 0.22 . A porosity of 0.20 was selected as a conservative estimate. In estimating hydraulic conductivity, the 
Table 2. Velocity of ground-water flow near the saltwater front, spring conditions

\begin{tabular}{|c|c|c|c|c|}
\hline Parameter & $\begin{array}{l}\text { Hillsborough } \\
\text { section }^{1}\end{array}$ & $\begin{array}{l}\text { Manatee } \\
\text { section }^{1}\end{array}$ & $\begin{array}{l}\text { Sarasota } \\
\text { section }^{1} \\
\end{array}$ & Average \\
\hline $\begin{array}{l}\text { Transmis- } \\
\text { sivity, } T \\
\left(\mathrm{ft}^{2} / \mathrm{d}\right) \\
\end{array}$ & 120,000 & 120,000 & 120,000 & 120,000 \\
\hline $\begin{array}{l}\text { Thickness, } \\
b(\mathrm{ft})\end{array}$ & 700 & 680 & 580 & 653 \\
\hline $\begin{array}{l}\text { Hydraulic } \\
\text { conductiv- } \\
\text { ity, } K \\
(\mathrm{ft} / \mathrm{d}) \\
\end{array}$ & 171 & 176 & 207 & 185 \\
\hline Porosity, & 0.2 & 0.2 & 0.2 & 0.2 \\
\hline $\begin{array}{l}\text { Gradient, } I \\
(\mathrm{ft} / \mathrm{ft}) \\
\text { May } 1976 \\
\text { May } 2000 \\
\end{array}$ & $\begin{array}{l}3.00 \times 10^{-4} \\
4.13 \times 10^{-4}\end{array}$ & $\begin{array}{l}3.88 \times 10^{-4} \\
4.34 \times 10^{-4} \\
\end{array}$ & $\begin{array}{l}2.87 \times 10^{-4} \\
3.34 \times 10^{-4} \\
\end{array}$ & $\begin{array}{l}3.25 \times 10^{-4} \\
3.94 \times 10^{-4} \\
\end{array}$ \\
\hline $\begin{array}{l}\text { Velocity, } v \\
(\mathrm{ft} / \mathrm{d}) \\
\text { May } 1976 \\
\text { May } 2000\end{array}$ & $\begin{array}{r}0.26 \\
.35\end{array}$ & $\begin{array}{r}0.34 \\
.38\end{array}$ & $\begin{array}{r}0.30 \\
.35\end{array}$ & $\begin{array}{r}0.30 \\
.36 \\
\end{array}$ \\
\hline
\end{tabular}

${ }^{1}$ See figure 16 for locations of sections.

thickness of the lower part of the aquifer was used rather than the full aquifer thickness; this was done because most of the integrated aquifer transmissivity occurs in the lower part. The result was higher computed hydraulic conductivities than if the full aquifer thickness had been used.

In figure 17 , the computed distances of groundwater movement are based on sustaining the May gradients continuously for the time shown. In fact, however, the May gradients are not sustained continuously but occur only seasonally each year. Historically, the potentiometric surface has recovered and a seaward gradient reestablished during each rainy season. This periodic occurrence tends to reverse, or at least retard, the landward migration of the saltwater front. The rise in potentiometric surface each fall does not completely offset encroachment, however, because flushing of saltwater is less easily accomplished than intrusion, and because cyclic pulses of seasonal rise and fall of the potentiometric surface tend to broaden the zone of transition. In addition, the retardation process would become decreasingly effective during 1976-2000 because of the expected long-term decrease in seaward gradients near the front, as indicated by the change in potentiometric surface between November 1976 and October 2000 (fig. 14). Thus, the overall effect is probably a net landward encroachment each year, at a net rate that is unknown but less than the estimated average May rate of $0.33 \mathrm{ft} / \mathrm{d}$.

The preceding analyses and discussions are all based on generalized regional conditions. Local conditions may differ considerably from the regional picture, and flow rates in these local areas may be much lower or greater than the regional values used in the regional analyses. Steep hydraulic gradients occur near pumping wells, and hydraulic conductivities many times higher than average probably exist in some places because of the great areal variability in transmissivity and because of occurrences of well defined, highly permeable zones within the aquifer. For example, under the computed potentiometric gradients of May 1976 and May 2000 (table 2), ground water would move about $3-4 \mathrm{ft} / \mathrm{d}$ in zones that have hydraulic conductivities 10 times the average of $185 \mathrm{ft} / \mathrm{d}$ used in the analyses.

Ground-water development within the zone of transition may be expected to result in localized changes in chloride concentrations. Generally, the direction and magnitude of these changes are unpredictable because of the great areal and vertical variability of chloride concentration in the zone of transition. An increase in chloride concentration would be expected where development is near the saltwater front or in the upper part of the aquifer in areas where the lower part is occupied by saltwater.

\section{REGIONAL OBSERVATION WELLS}

Modeling results and evaluations of saltwater movement were used to assess regional needs for observation wells to monitor changes in potentiometric levels and water quality in the Floridan aquifer. The assessments were based on the premise that observation wells are most desirable in areas of greatest anticipated changes that could deleteriously affect the ground-water resource.

Observation wells to monitor potentiometric levels are desirable in eastern Manatee and western Har-

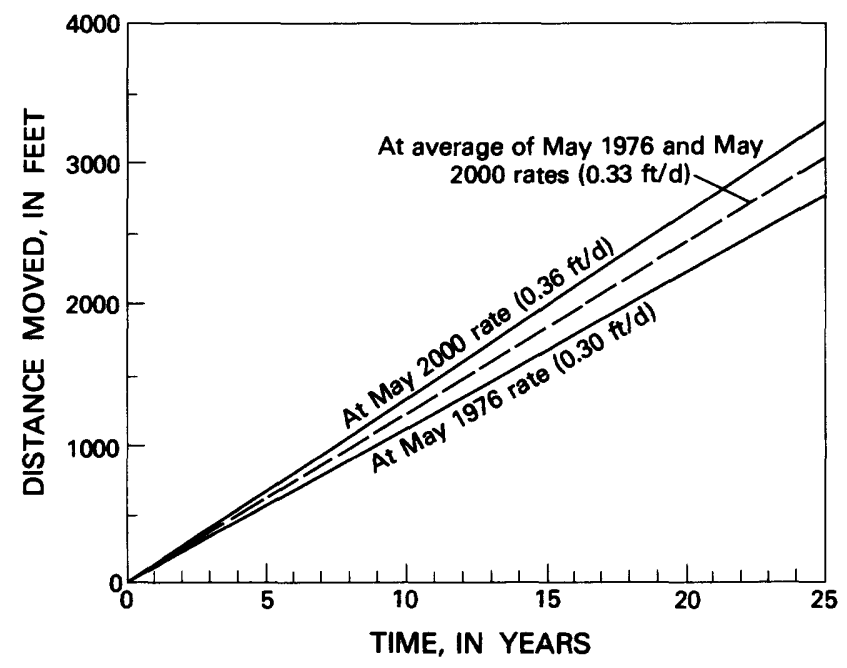

Figure 17. Rate of ground-water flow at saltwater front. 
dee Counties, on the basis of simulated declines in the potentiometric surface during 1976-2000. Declines of about 20-35 feet are expected to occur in both counties near the county line (figs. 12,14). As a result of these declines, the regional cone of depression centered in Manatee County is expected to deepen, broaden, and shift eastward during 1976-2000. By May 2000, the depression is projected to be in the eastern part of Manatee County, where the potentiometric surface will be about 30 feet below sea level (fig. 13).

Observation wells to monitor water-quality changes are desirable near the saltwater front, on its landward side, especially from mid-Sarasota County northward to Hillsborough County. In that area, the saltwater front is within the regional cone of depression in May 1976 and May 2000 (figs. 6, 7, 13). Computed rates of ground-water flow at three sections (fig. 16) indicate that landward movement of the saltwater front in May is both slow and areally uniform (table 2). Thus, a few wells uniformly spaced along the front would probably be as effective as an elaborate network of closely spaced wells. Observation wells are also desirable in central Manatee County near the toe of the saltwater front (fig. 8) for detecting possible upconing of the toe from near the base of the Floridan aquifer. These waterquality observation wells could also be used to monitor ground-water levels.

The lower part of the Floridan aquifer would probably be the first part of the aquifer to be affected by saltwater encroachment because the zone has a high transmissivity and is widely developed. Therefore, observation wells open to this zone could be effective in detecting encroachment before saltwater intrudes other parts of the aquifer.

Careful placement of observation wells could aid in making proper interpretations of the significance of water-quality changes. Because chloride concentrations within the zone of transition are highly variable, ground-water development could result in local changes in chloride concentration even if the regional saltwater front were not significantly affected. Thus, regional observation wells intended to monitor the saltwater front would be more effective if placed in areas relatively unaffected by local development.

\section{SUMMARY AND CONCLUSIONS}

An area of several thousand square miles in westcentral Florida was investigated to evaluate the effects of projected ground-water withdrawals during 1976-2000 on the saltwater front in the lower part of the Floridan aquifer. Simulated potentiometric levels obtained during a previous modeling investigation were used in the analysis.
The Floridan aquifer consists principally of limestone and dolomite and ranges in thickness from about 900 to 1,900 feet. The aquifer is bounded by a leaky upper confining bed and a lower confining bed that for modeling purposes was considered to be nonleaky. The principal water-bearing zone occurs in the lower part of the aquifer. The potentiometric surface fluctuates seasonally and is commonly lowest in May and highest in September or October. Seasonal withdrawals for irrigation are the principal cause of a large cone of depression, centered in Manatee County, that occurs each May.

Fresh ground water in inland parts of the modeled area contains chloride concentrations of 10-25 $\mathrm{mg} / \mathrm{L}$. Along the coast, seaward of the saltwater front, at least part of the Floridan aquifer contains saltwater, with chloride concentrations of about $19,000 \mathrm{mg} / \mathrm{L}$. In the intervening zone of transition, chloride concentrations are highly variable, both areally and with depth. The saltwater front in the lower part of the aquifer was within the major seasonal cone of depression of the potentiometric surface in May 1976.

The equilibrium position of a theoretical saltwater-freshwater interface under predevelopment conditions was computed using the Ghyben-Herzberg formula and a 1949 potentiometric-surface map. The computed equilibrium position of the interface at the top of the major water-bearing zone corresponds closely with the position of the saltwater front in the lower part of the aquifer.

The Floridan aquifer is the major source of water supply in the area. In 1975, withdrawals averaged 649 $\mathrm{Mgal} / \mathrm{d}$; by 2000 , withdrawals are expected to average $842 \mathrm{Mgal} / \mathrm{d}$. Pumping is principally for public supplies, phosphate-mining industry, and irrigation. Irrigation use is highly seasonal, with greatest amounts of water used in the spring and virtually none during the rainy summer months.

Simulated changes in the potentiometric surface from May 1976 to May 2000 ranged from a rise of about 10 feet in southwestern Polk County to a decline of about 35 feet in parts of Manatee and Hardee Counties. At least 5 feet of decline occurred along most of the coast. For November 1976 to October 2000, simulated changes ranged from a rise of about 15 feet to a decline of about 25 feet.

Computations of the rate of ground-water flow near the saltwater front in May 1976 and May 2000 were used as indications of the rate of movement of the saltwater front. Average landward flow rate along three sections in Hillsborough, Manatee, and Sarasota Counties was $0.30 \mathrm{ft} / \mathrm{d}$ in May 1976; the average rate was 0.36 $\mathrm{ft} / \mathrm{d}$ in May 2000, an increase of 20 percent. If sustained, the average rate of movement would result in the 
landward movement of the saltwater front of about half a mile between 1976 and 2000 .

From November 1976 to October 2000, simulated average coastward gradient near the saltwater front decreased by about $8.8 \times 10^{-5} \mathrm{ft} / \mathrm{ft}$. Because of other factors, the effects of this reduction on the saltwater front are unknown, but the reduction could contribute to a net landward movement of the front each year because of reduced coastward flow of fresh ground water toward the front.

Regional observation wells are desirable in western Hardee County, eastern Manatee County, and along the landward side of the saltwater front, from mid-Sarasota County to Hillsborough County.

On a regional basis, the analyses probably provide "worst case" results. However, where local conditions differ significantly from average regional conditions, flow rates may be substantially higher or lower than those computed.

From the analyses presented, the following conclusions are reached:

(1) Projected withdrawals during 1976-2000 are expected to deepen, broaden, and shift eastward the center of a regional cone of depression that develops each May in the potentiometric surface.

(2) Under existing pumping patterns, landward encroachment of the saltwater front in the lower part of the Floridan aquifer probably occurs during each irrigation season, between November and May. Encroachment is relatively uniform along the western periphery of the regional cone of depression. Probably some net landward movement occurs from year to year.

(3) Projected inland ground-water development during 1976-2000 would not significantly increase the May 1976 regional rate of movement.

(4) The net rate of landward movement of the front is probably so slow, under both existing and projected conditions, that under these conditions encroachment is not a present major threat to the regional freshwater resources for at least many decades ahead.

(5) Ground-water development within the zone of transition could result in modifications of the distribution of chloride concentration and could accelerate landward movement of the saltwater front.

(6) Local hydrogeologic conditions may be such as to result in encroachment rates in some areas many times those estimated for regional conditions.

(7) Regional observation wells for monitoring potentiometric levels would be particularly desirable in western Hardee County and eastern Manatee County. A few uniformly spaced wells for monitoring water-quality changes would be desirable along the saltwater front from midSarasota County to Hillsborough County and near the toe of the saltwater front in central Manatee County.

These conclusions are based on analyses of generalized regional conditions. They serve to provide a regional perspective on saltwater encroachment in westcentral Florida and can also serve as a basis for planning regional observation-well networks.

\section{REFERENCES}

Cooper, H. H., 1964, A hypothesis concerning the dynamic balance of fresh water and salt water in a coastal aquifer, in H. H. Cooper and others, Sea water in coastal aquifers: U.S. Geological Survey Water-Supply Paper 1613-C, p. C1-C12.

Domenico, P. A., 1972, Concepts and models in groundwater hydrology: McGraw-Hill Book Company, New York, $405 \mathrm{p}$.

Geraghty and Miller, Inc., and Reynolds, Smith and Hills, 1977, Hydrologic and engineering evaluation of the Four Rivers Basin area, west-central Florida: Consultants' Report for the Department of Army, Jacksonville District Corps of Engineers.

Hubbert, M. K., 1940, The theory of ground-water motion: Journal of Geology, v. 48, p. 785-944.

Kaufman, M. I., and Dion, N. P., 1967, Chemical character of water in the Floridan aquifer in southern Peace River basin, Florida: Florida Board of Conservation, Division of Geology, Map Series no. 27.

1968, Ground-water resources data of Charlotte, DeSoto, and Hardee Counties, Florida: Florida Division of Geology Information Circular no. 53, $22 \mathrm{p}$.

Lusczynski, N. T., 1961, Head and flow of ground water of variable density: Journal of Geophysical Research, v. 66 , no. 12 , p. $4247-4256$.

Ryder, P. D., Laughlin, C. P., and Mills, L. R., 1977, Potentiometric surface of Floridan aquifer, Southwest Florida Water Management District, September 1976: U.S. Geological Survey Open-File Report 77-353.

Stewart, J. W., Laughlin, C. P., and Mills, L. R., 1976, Potentiometric surface of Floridan aquifer, Southwest Florida Water Management District, May 1976: U.S. Geological Survey Open-File Report.

Stringfield, V. T., 1936, Artesian water in the Floridan peninsula: U.S. Geological Survey Water-Supply Paper 773-C, $195 \mathrm{p}$. 
Sutcliffe, H., Jr., 1975, Appraisal of the water resources of Charlotte County, Florida: Florida Bureau of Geology Report of Investigations 78, $53 \mathrm{p}$.

Trescott, P. C., Pinder, G. F., and Larson, S. P., 1976; Finitedifference model for aquifer simulation in two dimensions with results of numerical experiments: U.S. Geological Survey Techniques of Water-Resources Investigation, Book 7, chap. 1, 116 p.

U.S. Environmental Protection Agency, 1979, Final environmental impact statement, Central Florida phosphate industry, Background and alternatives assessment: EPA 904/9-78-026b, v. 2.

Wilson, W. E., 1977a, Simulated changes in ground-water levels resulting from proposed phosphate mining, westcentral Florida-preliminary results: U.S. Geological Survey Open-File Report 77-882, 46 p.

$1977 b$, Ground-water resources of DeSoto and Hardee Counties, Florida: Florida Bureau of Geology Report of Investigations $82,102 \mathrm{p}$.
Wilson, W. E., and Gerhart, J. M., 1979a, Simulated effects of ground-water development on potentiometric surface of the Floridan aquifer, west-central Florida: U.S. Geological Survey Open-File Report 79-1271, 119 p.

$1979 \mathrm{~b}$, Simulated changes in potentiometric levels resulting from ground-water development for phosphate mines, west-central Florida: Journal of Hydrology, Maxey Memorial Volume, p. 491-515.

Wolansky, R. M., Barr, G. L., and Spechler, R. M., 1979a, Configuration of the bottom of the Floridan aquifer, Southwest Florida Water Management District: U.S. Geological Survey Open-File Report 79-1490.

$1979 \mathrm{~b}$, Configuration of the top of the highly permeable dolomite zone of the Floridan aquifer, Southwest Florida Water Management District: U.S. Geological Survey Open-File Report 80-433. 